\title{
HYDROLOGIC CONNECTIONS AND DYNAMICS OF WATER MOVEMENT IN THE CLASSICAL KARST (KRAS) AQUIFER: EVIDENCE FROM FREQUENT CHEMICAL AND STABLE ISOTOPE SAMPLING
}

\author{
HIDROGEOLOŠKE POVEZAVE IN DINAMIKA PRETAKANJA \\ VOD V VODONOSNIKU KLASIČNEGA KRASA: IZSLEDKI \\ POGOSTIH KEMIČNIH IN IZOTOPSKIH ANALIZ
}

\author{
Daniel H. DOCTOR ${ }^{1}$
}

\begin{abstract}
UDC 556.34.044

Daniel H. Doctor: Hydrologic connections and dynamics of water movement in the classical Karst (Kras) aquifer: Evidence from frequement chemical and stable isotope samoling A review of past research on the hydrogeology of the Classical Karst (Kras) region and new information obtained from a twoyear study using environmental tracers are presented in this paper. The main problems addressed are 1) the sources of water to the Kras aquifer resurgence zone-including the famous $\mathrm{Ti}$ mavo springs- under changing flow regimes; 2) a quantification of the storage volumes of the karst massif corresponding to flow regimes defined by hydrograph recessions of the Timavo springs; and 3) changing dynamics between deep phreatic conduit flow and shallow phreatic and epiphreatic storage within the aquifer resurgence zone as determined through changes in chemical and isotopic composition at springs and wells. Particular focus was placed on addressing the long-standing question of the influence of the Soča River on the ground waters of the aquifer resurgence zone. The results indicate that the alluvial aquifer supplied by the sinking of the Soča River on the northwestern edge of the massif contributes approximately $75 \%$ of the mean annual outflow to the smaller springs of the aquifer resurgence zone, and as much as $53 \%$ to the mean annual outflow of the Timavo springs. As a whole, the Soča River is estimated to contribute $56 \%$ of the average outflow of the Kras aquifer resurgence. The proportions of Soča River water increase under drier conditions, and decrease under wetter conditions. Time series analysis of oxygen stable isotope records indicate that the transit time of Soča River water to the Timavo springs, Sardos spring, and well B-4 is on the order of 1-2 months, depending on hydrological conditions. The total baseflow storage of the Timavo springs is estimated to be 518 million $\mathrm{m} 3$, and represents $88.5 \%$ of the storage capacity estimated for all flow regimes of the springs. The ratio of baseflow storage volume to the average annual volume discharged at the Timavo springs is 0.54 . The Reka River sinking in Slovenia supplies substantial allogenic recharge to the aquifer; however, its influence on the northwest
\end{abstract}

Izvleček

UDK 556.34.044

Daniel H. Doctor: Hidrogeološke povezave in dinamika pretakanja vod v vodonosniku klasičnega Krasa: izsledki pogostih kemičnih in izotopskih analiz

$\mathrm{V}$ članku predstavim pregled dosedanjih hidrogeoloških raziskav klasičnega Krasa in nova spoznanja, ki temeljijo na dvoletni študiji naravnih sledil. Osredotočim se na tri probleme: 1) izvor voda $v$ izvirih vodonosnika Krasa ob različnih vodostajih, vključno z izvirom Timave, 2) ocena volumnov zalog kraškega masiva v odvisnosti od pogojev toka, ki jih razberemo iz recesijske krivulje izvira Timave; 3 ) uporaba analize sprememb izotopske sestave vode na izvirih in $\mathrm{v}$ vrtinah pri študiji spremenljive dinamike med dotokom iz prevodnikov globoke freatične cone ter iz zalog plitve freatične in epikraške cone v izvirnem območju vodonosnika. Podrobno obravnavam že dalj časa aktualno vprašanje vpliva reke Soče na podzemne vode izvirnega območja. Izsledki kažejo, da aluvijalni vodonosnik, ki ga napaja Soča, prispeva približno $75 \%$ povprečnega letnega iztoka manjših izvirov izvirnega območja in do $53 \%$ povprečnega letnega iztoka izvira Timave. Skupaj Soča prispeva kar 56\% celotnega iztoka izvirnega območja Krasa. Relativni prispevek Soče je večji v sušnem obdobju. Iz analize časovnih vrst vrednosti meritev stabilnih izotopov kisika smo ocenili, da je potovalni čas vode med reko Sočo in izviroma Timavo in Sardočem (in tudi vrtino B-4) 1-2 meseca, odvisno od hidroloških razmer. Celotni volumen zalog baznega toka Timave ocenjujemo na 518 milijonov kubičnih metrov, kar predstavlja 88,5\% celotnih zalog, ocenjenih za vse pogoje toka na izvirih. Razmerje med volumnom zalog baznega toka in volumnom povprečnega letnega iztoka Timave je 0.54. Reka Reka, ki ponira v Sloveniji, je pomemben vir alogenega napajanja vodonosnika, a je njen vpliv na severozahodnem delu izvirnega območja omejen predvsem na izvire Timave. Reka predstavlja pomembno komponento pretoka na izviru zgolj ob poplavnih dogodkih, ki trajajo od nekaj dni do nekaj tednov. Trajnostno upravljanje čezmejnega vodonosnika Krasa je mogoče zgolj z zagotavljanjem visoke kakovosti vode reke Soče, prav tako pa bo potrebno izvesti še več natančnih sledilnih poskusov v epikraški coni vodonosnika, s

${ }^{1}$ U.S. Geological Survey, 12201 Sunrise Valley Drive, Reston, VA 20192, USA, dhdoctor@usgs.gov

Received/Prejeto: 19.09.2007 
resurgence zone is limited to the Timavo springs, and is only a significant component of the spring discharge under flood conditions for relatively brief periods (several days to weeks). Sustainability of the trans-boundary aquifer of the Kras will benefit from maintaining high water quality in the Soča River, as well as focused water tracing experiments within the epiphreatic zone of the aquifer to better delineate the recharge zone and to identify sources of potential contamination to the Brestovica water supply well.

Keywords: Classical Karst, Kras, aquifer, chemistry, stable isotopes, hydrograph recession, Slovenia, Italy. katerimi bi določili izvor onesnaženja vode v vrtini vodnega vira Brestovica .

Ključne besede: Klasični Kras, vodonosnik, kemija, stabilni izotopi, recesija hidrograma, Slovenija, Italija.

\section{INTRODUCTION}

The Classical Karst of southwest Slovenia and north of Trieste, Italy, is a high limestone plateau that stands above the Adriatic Sea at the Gulf of Trieste. The region is the type locality of karst terrains, having been first described by Valvasor in 1689 (Kranjc, 1997). In the Slovene usage, the word kras is a place-name for this region, as well as a term which once implied a landscape that is barren, rocky, and without available water (Gams, 1993). For centuries, the term was a fitting description of the Classical Karst, and the region still bears the place-name, $\mathrm{Kras}^{1}$. The Kras region is noted for its lack of readily available water resources in spite of an abundance of precipitation. Roughly $1400 \mathrm{~mm}$ of precipitation fall annually on the $440 \mathrm{~km}^{2}$ region, yet the inhabitants of this sparsely populated region have historically relied upon elaborate systems designed to collect rainfall from rooftops and store the water in artificial cisterns and ponds (Kranjc, 1997; Ravbar, 2004). The reason for the absence of surface runoff is the intense karstification of the uplifted block of Cretaceous carbonate rocks, exacerbated by centuriesold deforestation and soil loss, which permits rapid internal drainage of precipitation (Gams, 1993). Several large springs are located along the Adriatic coast in Italy on the low northwestern edge of the Kras region (Fig. 1). Collectively, these springs have an average annual discharge of $35 \mathrm{~m}^{3} / \mathrm{sec}$ (Gemiti, 1984a). Although the springs of the aquifer resurgence rise in Italy, they are supplied to great degree by precipitation and allogenic runoff originating in Slovenia. Thus, the aquifer of the Kras is also a classical example of a trans-boundary aquifer.

This paper is presented in two parts: the first part is an overview of previous research on the hydrogeology of the Kras region. The second part is a summary of the results of a two-year study employing natural chemical and isotopic environmental tracers to better understand the dynamics of water movement within this complex carbonate aquifer system.

\section{PREVIOUS HYDROGEOLOGICAL RESEARCH ON THE KRAS AQUIFER}

\section{GEOLOGIC SETTING OF THE KRAS}

The Kras region is a high plateau overlooking the Gulf of Trieste at the northernmost part of the Adriatic sea (Fig. 1). The Kras is $40 \mathrm{~km}$ long, up to $13 \mathrm{~km}$ wide, and covers approximately $440 \mathrm{~km}^{2}$ (Krancj, 1997). The stratigraphic sequence consists of carbonate rocks (limestones and dolomites) overlain by turbiditic argillaceous sandstone and shale (flysch). The sediments were deposited from early Cretaceous to Eocene, when a large carbonate platform was deposited, then drowned and capped by the flysch sediments during active tectonic uplift (Cucchi et al.,

\footnotetext{
${ }^{1}$ This region is the Classical Karst in English, Kras in the Slovene language, and il Carso in the Italian language. In this paper, the region will hereafter be referred to by its Slovene name, Kras. Other place names and physical geographic features are referred to by their respective Slovene and Italian names whenever appropriately situated within the respective country. Two exceptions are the Soča and Vipava rivers, which originate in Slovenia before crossing the international border into Italy, and are therefore referred to by their Slovene names throughout this paper, regardless of whether the point along the river that is being referred to lies within Slovenia or Italy.
} 


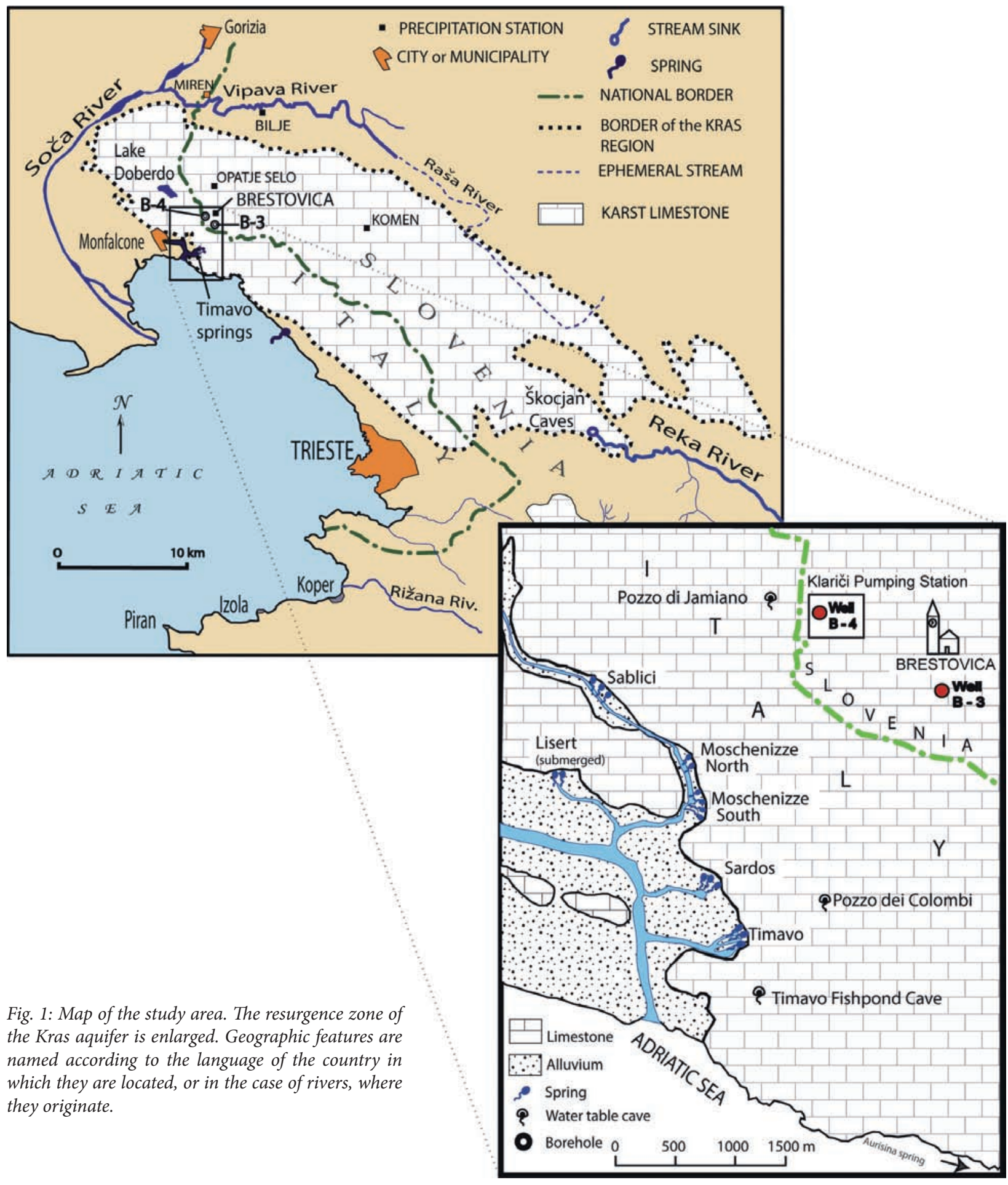

1987). The entire sequence was later uplifted and strongly folded and faulted. The Kras region lies on the AdriaticDinaric tectonic plate, which collided with the Euroasian plate to the north in the early Eocene (roughly 50 million years ago). This tectonic collision caused the uplifting of the Julian Alps, strong faulting and folding of the rocks between the Julian Alps and the Adriatic Sea, and the drowning of the carbonate platform (Šebela, 1997). This process of orogenesis has continued from the Eocene to the present, and is still active today.

The plateau of the Kras itself is formed by the large overturned Trieste-Komen anticline that plunges to the 


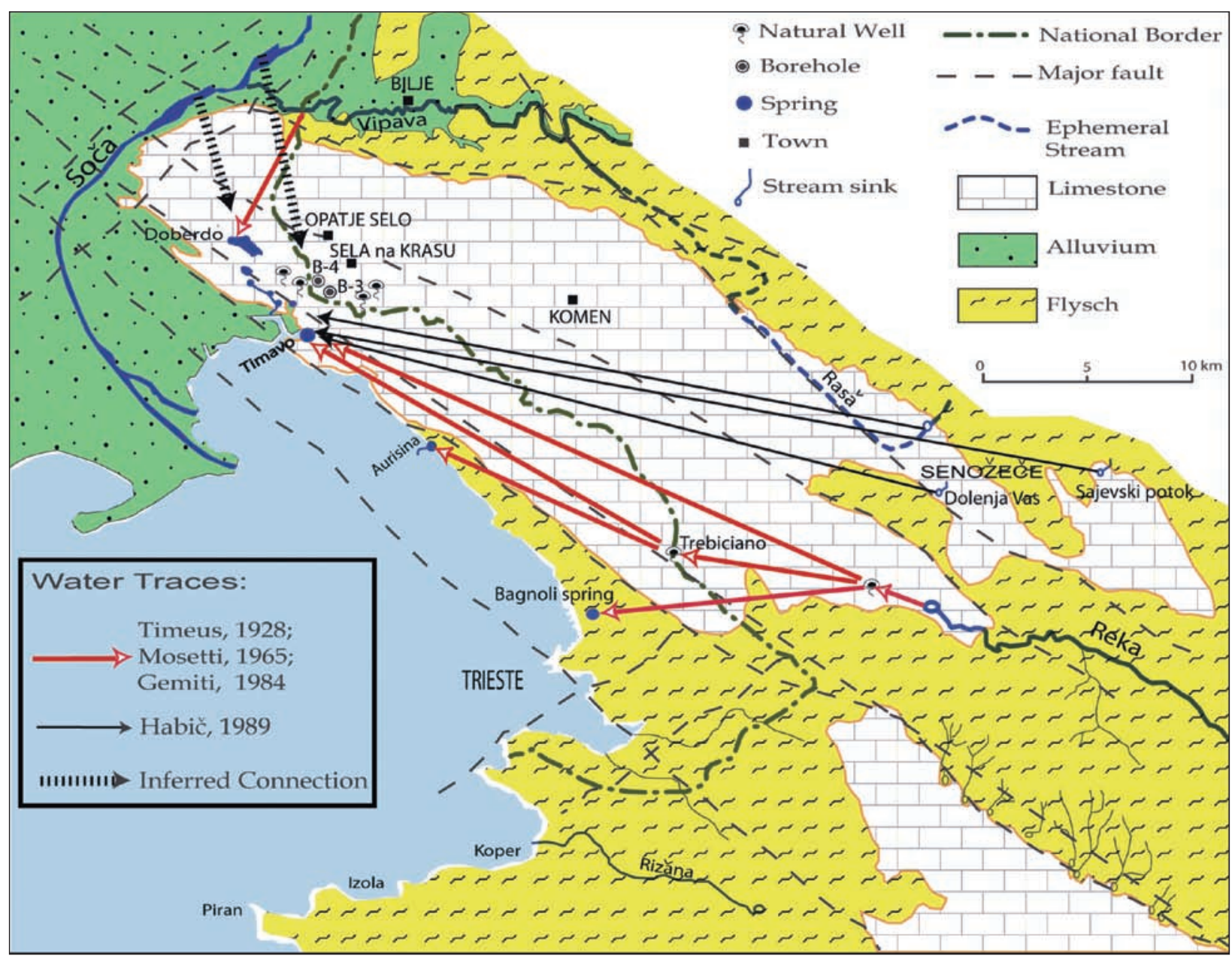

Fig. 2: Geology of the Kras and summary of some water tracing results

northwest, extending along the Adriatic coast. Erosion has stripped the flysch rocks off of the surface of the plateau, exposing the carbonates within the core of the anticline. This anticline is bounded by the Trieste fault along the Adriatic coast to the southwest, and to the northeast by the Raša fault. Both of these large thrust faults trend NW-SE, and form hydrogeologic boundaries along the edge of the Kras by bringing up the siliceous, relatively impermeable flysch layers into contact with the karstified limestones, while a third fault runs down the axis of the anticline and may be a more permeable pathway for ground water flow (Fig. 2). The result is that the high Kras plateau is effectively bound by less permeable rocks on its northern and southern borders, as well as at depth. On the southeast border, the Reka River flows on flysch terrain from its eastern source in Croatia until it encounters the limestone bedrock, and then sinks. The Reka River enters this block of rock, sinking into the Kras at the base of a $100 \mathrm{~m}$ high limestone cliff at the Škocjan Caves.
On the northwestern side of the Kras, the plateau surface abruptly slopes down to sea level and opens into the plain of the Soča River. Here, the ground-water of the karst aquifer resurges in a narrow zone of artesian springs on the southwestern edge, as a result of the prevailing dip of the rock layers being west-southwest. No surface streams exist on the plateau, and runoff is negligible. Given the abundant annual precipitation, highly permeable land surface, and lack of surface water runoff, precipitation on the Kras surface is a major component of recharge to the underlying aquifer. Geologic structure has been demonstrated to be a primary controlling factor on the development of the Kras aquifer and its compartmentalization of drainage (Cucchi et al., 2001).

\section{MUNICIPAL WATER SUPPLIES}

The Timavo springs were once the primary water supply for the city of Trieste. However, Trieste and the other Italian towns along the Adriatic coast in the region cur- 
rently receive their water supply from a series of pumping wells drilled into the alluvial aquifer of the Soča River plain, west of the river and south of the city of Gorizia. The wells were constructed after a chemical spill into the Reka River in 1972 jeopardized the continued use of the Timavo springs as the primary water supply for Trieste. Sardos spring is still currently utilized for water supply of Trieste (A.C.E.G.A. Trieste, 1988).

The water supply of the Slovenian Kras region comes from a pumping station that taps into the karst aquifer on the northwestern edge of the Kras, very near the international border between Italy and Slovenia. Several exploratory boreholes were drilled, ten of which are active piezometers for monitoring water level fluctuations and for water sampling (Krivic, 1981). The chosen site is the Klariči pumping station, which is located in the Brestovica Valley, $2 \mathrm{~km}$ west of the town of Brestovica. Hereafter this sampling point shall be referred to as well B-4, in keeping with the notation of Krivic (1982a). Well B-4 is screened from $14 \mathrm{~m}$ to $68 \mathrm{~m}$ depth and more than $1 \mathrm{~m}$ of the borehole intersects an open karst conduit. Both the production wells and the monitoring well B-4 intersect the same flowing karst conduit, and therefore draw the same water (samples for this study were taken from the monitoring well at the pumping station, located 3 meters distant from the main pumping wells). The site is situated at an altitude of 16 meters above sea level (m.a.s.l.) approximately $4 \mathrm{~km}$ north of the Adriatic coast, and lies within a karst doline located along the international
In addition to well B-4, another of these boreholes, well B-3, was repeatedly sampled during this study. Well B-3 is located approximately $1.5 \mathrm{~km}$ to the southeast of the Klariči pumping station. Details on the construction of these two wells is provided in Table 1. Both wells extend more than $40 \mathrm{~m}$ below sea level (m.b.s.l.), thus intersecting a large portion of both the unsaturated and phreatic zones of the aquifer. At well B-3, depth to water during sampling usually ranged between $+2 \mathrm{~m}$ to $-10 \mathrm{~m}$ with respect to sea level, however during a sampling trip in August of 1999, the bailer hit sediment at the bottom of the borehole at a depth of $-10 \mathrm{~m}$, and the well was dry. Thus, the well is completed within the epiphreatic zone of fluctuation of the local water table, and has become partially filled with sediment. Since this well normally held water, it was of particular interest and was frequently sampled in the present study. Usually, the water level in the well at the time of sampling was between +2.0 and +3.0 m.a.s.l. On two occasions, in the late summer of both 1999 and 2000, the well water had a distinct smell of hydrogen sulfide gas, indicating reducing conditions in the ground-water.

The coefficient of correlation between phreatic water level measurements monitored for the period between April 1977 to January 1980 in well B-4 and well B-3 was 0.99 (Krivic, 1982a). Thus, the boreholes are hydraulically connected; however well B-4 is within bedrock which is more intensively karstified than B-3, as evidenced by the measured transmissivities at both sites (Table 1).

\begin{tabular}{|l|l|l|}
\hline PARAMETER & Monitoring Well B-4 & Monitoring Well B-3 \\
\hline Elevation (top of casing) & 18.0 m.a.s.l. & 40.7 m.a.s.l \\
\hline Depth ( below sea level) & 52.5 m.b.s.l. (open fracture from 41.7-43.0 m.b.s.l.) & 44.6 m.b.s.l. \\
\hline Screen interval & $14 \mathrm{~m}$ to $68 \mathrm{~m}$ depth & Unknown \\
\hline Water table elevation (range) & $0.5-3.5 \mathrm{~m}$. a.s.l. & $<0.0-3.0 \mathrm{~m}$. a.s.l. \\
\hline Transmissivity (T) & $>1 \times 10^{-1} \mathrm{~m}^{2} / \mathrm{s}$ & $2 \times 10^{-6} \mathrm{~m}^{2} / \mathrm{s}$ \\
\hline Hydraulic conductivity (K) & $>8 \times 10^{-4} \mathrm{~m} / \mathrm{s}$ & $4 \times 10^{-7} \mathrm{~m} / \mathrm{s}$ \\
\hline Geologic material & $0-0.5 \mathrm{~m}(\mathrm{soil})$ & $0-2 \mathrm{~m} \mathrm{Soil}$ \\
& $0.5-52.5 \mathrm{~m}$ Cretaceous limestone & $2-85.3 \mathrm{~m}$ Cretaceous limestone \\
\hline
\end{tabular}

Tab. 1: Well log and pump test data for Well B-4 and Well B-3

border between Italy and Slovenia. The average water table elevation at the site is 2.0 m.a.s.l. A pumping test conducted with simultaneous sampling of chemical and isotopic parameters in mid-August of 1995 showed that the Klariči source can produce more than $250 \mathrm{~L} / \mathrm{s}$ with a drawdown of only $0.5 \mathrm{~m}$ (Urbanc and Kristan, 1998). No intrusion of seawater occurred during the pumping test, indicating that fresh ground-water exists to depths greater than 50 meters below sea level.

\section{TRACING EXPERIMENTS IN THE REKA-TIMAVO SYSTEM}

Past hydrogeological research on the Kras focused mainly on the source of water of the Timavo springs and on the dynamics of the subterranean course of the Reka River (Kranjc, 1997). The Timavo springs are the largest natural source of ground-water in the region, with a mean annual discharge of $30.2 \mathrm{~m}^{3} / \mathrm{sec}$ representing approximately 
$85 \%$ of the average measured outflow of the aquifer resurgence (Civita et al., 1995). A comprehensive historical account of the history of the hydrogeologic research conducted on the springs is found in the book Timavo: Esplorazione e Studi by Galli (1999).

It was generally recognized that two other nearby rivers could also influence the Kras aquifer resurgence: the Vipava River to the north, and the much larger Soča River to the west. In an experiment using lithium-chloride and strontium-chloride salts, a connection was discovered between these other karst springs and the Vipava River that was seemingly independent of the Timavo springs (Timeus, 1928) (Fig. 2). In addition, an 80 $\mathrm{m}$ deep borehole located near Miren where the Vipava River crosses the international border lost drilling water during construction between depths of $64 \mathrm{~m}$ to 80 $\mathrm{m}$, indicating karstic conduits at depth (Bidovec, 1967). The discharge of the Soča River to the west, on the other hand, is much larger; however, a direct artificial trace has never been conducted between the Soča River and the springs of the Kras resurgence zone. Conducting a water trace is complicated by the fact that the Soča River flows on a thick accumulation of alluvium, and not on bedrock. This means that a clearly identifiable sinking point cannot be easily located (Bidovec, 1967). However, losses from the Soča River have been gauged along $12 \mathrm{~km}$ of the river's course between the towns of Gorizia and Gradisca. Estimates of flow loss are on the order of $20-25 \mathrm{~m}^{3} / \mathrm{sec}$, which reflects approximately $10 \%$ of the river's total discharge upstream at Gorizia during average flow conditions (Mosetti and D’Ambrosi, 1963; A.C.E.G.A. Trieste, 1988). Measurements of piezometric water levels in the alluvial aquifer surrounding the Soča River indicate an area of focused ground-water loss between the river and the elevated Kras plateau (Mosetti and D'Ambrosi, 1963). These water table troughs are elongated in the same direction as faults trending northeast-southwest that have been determined through geophysical exploration (Morgante et al., 1966).

It was not until 1962 that the second significant tracing experiment conducted on the Reka-Timavo system took place. In this study, tritium was used as the primary tracer (Eriksson et al., 1963; Mosetti, 1965). The experiment was initiated during low flow, with the hope that the baseflow contribution of the Reka River to the Timavo spring discharge could be quantitatively deduced. On July $3^{\text {rd }}, 1962,200$ Curies of tritium and $100 \mathrm{~kg}$ of fluorescein were injected at the entrance of the Škocjan Caves, where the sinking flow of the Reka River was gauged to be $0.5 \mathrm{~m}^{3} / \mathrm{sec}$ (Gemiti, 1984b). The flow at the Timavo springs, despite not being quantitatively gauged, was estimated at the time of tracer injection to be $10 \mathrm{~m}^{3} / \mathrm{sec}$. However, the trace was interrupted by a large storm event on the day of injection, such that the Reka flow increased to $30 \mathrm{~m}^{3} / \mathrm{sec}$ and the Timavo discharge increased to an estimated $62 \mathrm{~m}^{3} / \mathrm{sec}$ two days after tracer injection (Gemiti, 1984a). The initially reported recovery of tritium at the Timavo springs during the tracing experiment was only $50 \%$ of the injected tracer mass (Mosetti, 1965). The low amount of reported tracer recovery immediately lead to new ideas and theories about the fate of the underground Reka, and the source of the majority of the water issuing from the Timavo springs.

However, at least two authors have since pointed out that the interpretations of this experiment were based upon faulty hydrologic data and that the results should be reconsidered (Bidovec, 1967; Gemiti, 1984a; Gemiti, 1996). The Reka River in fact begins to sink a few kilometers upstream of the tritium injection point, near the Cerkvenik Mill. In earlier experiments, water disappearing at this sinking point had been traced to connect with the flow in the Škocjan Caves. At the time of injection of the tritium, the actual flow of the Reka measured upstream of the injection point at the Cerkvenik Mill was $1.2 \mathrm{~m}^{3} / \mathrm{sec}$, a factor of 2.4 times greater discharge than that used in the calculations to determine tracer recovery at the Timavo Springs (Bidovec, 1967). Moreover, Gemiti (1984a) concluded that the discharge at the Timavo springs during the trace was actually twice as great as initially supposed, and argues that instead of 50\% tracer recovery reported in the results of Eriksson et al. (1963), practically all of the tritium that was injected was discharged from the Timavo springs and in small part from the springs of Aurisina. Due to uncertainties in the flow estimations, however, the interpretation of this test is left ambiguous. Nonetheless, Gemiti (1984a) estimated the ratio of the total Reka River flow to the Timavo springs discharge across the transit time (i.e., time elapsed between tracer injection at the input and its initial detection at the outlet) to be $1: 4.4$, corresponding to $23 \%$ of Reka River water discharged at the springs, assuming all of the Reka river flow during that time went to Timavo.

Very few controlled tracer experiments have been conducted on the Reka-Timavo system after 1962. In 1972, an accidental hydrocarbon spill occurred into the Reka River when a truck carrying several tons of fuel oil overturned on the road alongside the river, approximately $18 \mathrm{~km}$ upstream of the river's sinking point at the Škocjan Caves (Gemiti, 1998). At that time the Timavo springs were still in use as a drinking water supply to the city of Trieste, and the Slovenian authorities immediately informed the A.C.E.G.A. Trieste utility. The fast response enabled a close monitoring of the water chemistry of the Reka River at Škocjan Caves, the Timavo springs, and other springs of the aquifer resurgence, thus allowing the use of the pollutants as a tracers. The frequency of water 
sampling was every hour at the Timavo springs, every two hours at Aurisina, and twice per day at Sardos. The contaminant spill occurred under high flow conditions of the Reka River and Timavo springs (median flows of $13.5 \mathrm{~m}^{3} / \mathrm{sec}$ and $42.5 \mathrm{~m}^{3} / \mathrm{sec}$, respectively). During these high flow conditions the transit time between the Reka River and Timavo springs was 5 days and Gemiti (1998) estimated the ratio of river discharge to spring discharge across the transit time was 1:1.6, corresponding to $63 \%$ of Reka River water discharged at the Timavo springs, again assuming all the Reka flow went to Timavo. However, the initial detection of the pollutants was observed first at Aurisina spring, and 12 hours later at the Timavo springs. The peak of the breakthrough curves occurred two days later, first again at Aurisina and three hours later at Timavo. No pollutants were detected at Sardos spring, even when the highest concentrations of the pollutants were observed at Timavo and Aurisina springs. The pollutant concentrations decreased to below detection limit in a matter of hours at Aurisina, while the recession curve of the pollutant concentrations at Timavo extended for 3 days after the peak (Gemiti, 1998).

Gemiti (1998) also discussed three traces that were conducted between the deep karst shaft located at Trebiciano (Fig. 2) and the Timavo springs: one with tritium in 1962, and two with carbon tetrachloride $\left(\mathrm{CCl}_{4}\right)$ in 1982 (note: tritium should not be used as a tracer due to its radioactivity, and carbon tetrachloride should not be used as a tracer due to its toxicity; several non-toxic fluorescent dyes are commonly available as alternatives). Both the tritium trace and the first $\mathrm{CCl}_{4}$ trace were conducted under moderate flow (the median flows of Timavo and Reka from time of injection to peak detection of the $\mathrm{CCl}_{4}$ tracer were 7.1 and $32 \mathrm{~m}^{3} / \mathrm{sec}$, respectively), while the second $\mathrm{CCl} 4$ trace was conducted during a large flood event (median daily flows of Timavo and Reka were 96 and $50 \mathrm{~m} 3 / \mathrm{sec}$, respectively) (Gemiti, 1984b). The transit times of the 1962 and first 1982 trace from Trebiciano to Timavo were 10.5 days and 10.0 days respectively, while the transit time of the second 1982 trace conducted during flood flow was only 2.7 days. Estimates of the percentage of Reka River discharged at the Timavo springs during the trace of 1962 across the transit time from Trebiciano to Timavo was $18 \%$; however, this value again assumes all of the Reka flow went to Timavo, and is not corrected for tracer recovery due to a lack of reliable flow data. The estimated values of percentage of Reka River discharge exiting at Timavo for the 1982 traces from Trebiciano conducted with $\mathrm{CCl}_{4}$ were $19 \%$ for the moderate flow trace, while for the high flow trace the estimated percentage was $48 \%$. However, the amount of $\mathrm{CCl}_{4}$ recovered in the first 1982 trace was $78 \%$, while only $32 \%$ was recovered during the high flow experiment. In addition, both the 1982 traces conducted with $\mathrm{CCl}_{4}$ have narrow, peaked tracer breakthrough curves showing total passage of tracer after 3 days for the first trace and 2 days for the second trace, as opposed to the broader curve of the Timavo spring discharge which remained at elevated flow for 4 and 9 days, respectively.

The results presented by Gemiti (1998 and 1984b) are summarized in Fig. 3. Note that when the calculated percentages of Reka River water at Timavo are adjusted for tracer recovery this results in a lower percentage of Reka water expressed at Timavo than previously estimated, averaging around $15 \%$ for the two traces from the shaft Trebiciano conducted with $\mathrm{CCl}_{4}$ in 1982, one (1982b) having occurred under very high flow conditions. The percentage of Reka water estimated from the 1972 trace is questioned given the lack of control over the experiment as the injection was due to an accidental hydrocarbon spill. These results highlight the necessity of controlled quantitative tracer recovery for accurately determining the proportion of the Reka River expressed at Timavo. In spite of the need for more quantitative data, these traces do confirm the existence of a conduit connection of large dimension between the Reka River and the Timavo springs, with a travel time of on the order of $600 \mathrm{~m} / \mathrm{hr}$ (Gemiti, 1984b \& 1998). After the course of the underground river passes the shaft at Trebiciano, the main conduit is phreatic and extends below sea level (Boegan, 1938). The ratio between the total discharge of the Reka River and that of the springs during the transit time of the tracer is an important comparison, for it provides an estimate of the maximum volume of water emptied from the aquifer system that could result from the river input in that time period. However, these percentages are overestimates since they assume all of the Reka River flow measured during the underground passage of the tracer exits at the Timavo springs; in fact, it has already been established that some portion of the subsurface Reka flow comes out at Aurisina spring along the coast, and also at Bagnoli spring further inland under high flows. Therefore, a major fraction of the Reka River flow sinking at the Škocjan caves exits from the Timavo springs, but some flows elsewhere. The complex hydraulic phenomena in the aquifer provide additional difficulty in determining how much of the Reka River flows out of the Timavo springs.

More recent research on the function of the RekaTimavo system has focused on continuous monitoring of water levels and physico-chemical parameters such as temperature and electrical conductivity between the sinking point of the Reka River and its underground course where it is accessible via deep shafts (Cucchi et al., 1997; Cucchi et al., 2000; Cucchi et al., 2002; Gabrovšek 


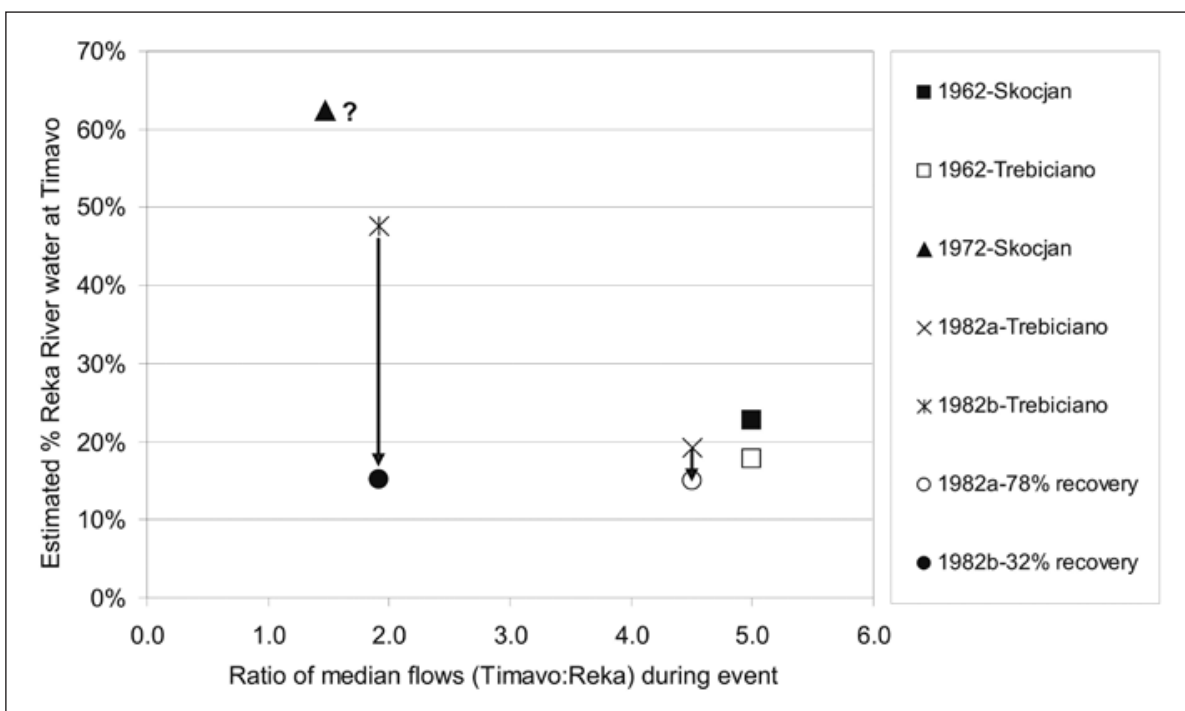

Fig. 3. Estimated maximum percentage of Reka River water exiting at the Timavo springs plotted against the ratio of median flow of Timavo to median flow of Reka during each trace event. The date and injection point of the tracer is indicated in the legend (data from Gemiti, 1984b and Gemiti, 1998).

and Peric, 2006). These studies have provided valuable information on the hydraulics of the system. The most recent dye tracing results on the Reka-Timavo system were reported by Peric et al. (2007). They released $5 \mathrm{~kg}$ of uranine tracer dye into the Reka River on Sept. 4, 2006 at the sinking point on the contact between the flysch and limestone. Dye was detected in low concentrations at the Timavo springs 32 days after release under relatively low flow conditions; a single $35 \mathrm{~mm}$ rain event occurred during the trace, which enabled a more rapid transport of dye than prior to the event. Further analysis of these data is ongoing (Peric and Gabrovšek, personal communication, 2007).

\section{TRACING EXPERIMENTS FROM THE EASTERN KRAS}

Additional water tracing tests were conducted in the late 1980s by Slovenian researchers from the Karst Research Institute in Postojna (Habič, 1989). These were conducted from small sinks in the beds of ephermal streams located on the eastern edge of the Kras, most notably from the Raša Lakovnik (Raša River sink), the Sajevški potok (brook), and within the basin of Senožeče-Dolenja Vas (Fig. 2). All of these traces were conducted under low flow conditions. Rhodamine injected into the Raša Lakovnik was detected at the Timavo springs after 60 days, at Aurisina after 78 days, and at Sardos after 105 days. The biological tracers injected at Senožeče were detected at Aurisina after 75 days, and a connection with the Sablici spring was also proven. Fluorescein injected into the Sajevški Potok was detected first at the water supply well B-4 at Klariči 40 days after injection, at the Timavo springs after 70 days, and at both the Sardos and Aurisina springs 80-90 days after injection (Galli, 1999). These results proved the existence of additional sources of allogenic recharge to the aquifer from the northeastern edge of the Kras, but quantitative estimates of recharge were not made possible from the results, partly due to these all being ephemeral sources.

In spite of these studies, a question still remained: from where originates the unaccounted proportion of the discharge at the Timavo springs? This is an important question, for this water source provides the majority of the spring flow under low flow conditions.

\section{CHEMICAL AND STABLE OXYGEN ISOTOPIC COMPOSITIONS OF THE KRAS GROUND-WATERS}

On the basis of the variations in water chemistry and temperature measured by Gemiti and Liciardello (1977) and Cancian (1987), the ground-water of the aquifer resurgence can be divided into four separate groups of waters: 1) the water of the Timavo springs, 2) the water of Sardos and Moschenizze South springs, 3) the water of Doberdò Lake, Sablici springs and of Moschenizze North spring, and 4) the water of Aurisina spring, or the socalled "karst water" (Gemiti \& Licciardello, 1977; Gemiti, 1994).

These groupings were substantiated by later stable isotope (oxygen and carbon) analyses of the spring waters (Flora and Longinelli, 1989; Doctor et al., 2000). In addition, it was observed that the ground waters of the region all exhibit strong isotopic inversion in their $\delta^{18} \mathrm{O}$ values on an annual cycle (lower values in warmer spring and summer months, higher values in cooler fall and winter months) (see Fig. 6.) This observation is opposite to the expected isotopic composition if the springs were fed primarily by runoff from precipitation, given the influence of seasonal fluctuations in air temperature on the isotopic composition of rainfall (Dansgaard, 1964). The interpretation of Flora and Longinelli (1989) was that 
the karst springs receive most of their recharge from local precipitation on the Kras region in the winter, and from meteoric water falling at higher elevations (800-900 m.a.s.l. as opposed to the $400 \mathrm{~m}$ elevation of the Kras plateau) in the spring and summer months.

The overall result is a general shift in the average spring water $\delta^{18} \mathrm{O}$ to isotopic compositions that are lower than the weighted mean annual isotopic composition of meteoric precipitation on the Kras region (D'Amelio et al., 1994). The Kras region receives the majority of its precipitation in the fall and winter months (SeptemberFebruary). Although the winter rainfall on the Kras is generally more isotopically depleted in ${ }^{18} \mathrm{O}$ than the summer rainfall, the rain and snow precipitation in the Slovenian highlands is depleted even further still, a result of the "altitude effect" which often results in an isotopic depletion of $0.2 \% 0 / 100 \mathrm{~m}$ (Eriksson, 1983). By comparing the isotopic composition of the spring waters to that of the Soča River, Vipava River, and local precipitation, Flora and Longinelli (1989) concluded that only during the drier summer months when the local phreatic level is lowered do the Timavo and other springs of the resurgence receive recharge from a more isotopically depleted source. Their hypothesis was that this source would be derived from the inner Slovenian highlands in the region of Postojna and of Cerknica, to the far northeast of the resurgence zone and in fact outside of the previously delineated recharge zone of the Kras aquifer. This hypothesis was contrary to that of Gemiti \& Liciardello (1977) who attested to a more prevalent Soča River source, based upon the spring water chemistry data.

Later, Urbanc and Kristan (1998) estimated that approximately $50 \%$ of the water produced during a pumping test at well B-4 was derived from the Soča River based on concurrent oxygen stable isotopic measurements of the river and well water. This surface water component is manifested not only at the Klariči pumping well, but in the discharge of all of the major springs in the surrounding area, as demonstrated by studies of the chemistry and isotopic composition of the springs in comparison to that of the Soča River (Cancian, 1987; Longinelli, 1988; Flora and Longinelli, 1989; Krokos, 1998).

\section{INORGANIC CARBON ISOTOPES AS TRACERS}

The stable carbon isotopic composition $\left(\delta^{13} \mathrm{C}\right)$ of dissolved inorganic carbon (DIC) has been proven useful for distinguishing between the recharge areas for different karstic waters along with oxygen and hydrogen isotopes of water (Deines et al., 1974; Pezdič et al., 1986; Urbanc et al., 1997). In the Kras system, carbon isotopes can be used to distinguish between waters influenced by the Soča River versus waters influenced by more local recharge (Doctor et al., 2006). The annual range in the $\delta^{13} \mathrm{C}_{\text {DIC }}$ composition of the Soča River is between -6.5 and $-11.0 \%$, with regular seasonal oscillations in the carbon isotopic composition of the water (Urbanc et al., 1997). The most positive values occur in the early spring, and most negative values in the late fall. In the spring, the snowmelt from the mountainous regions of the Soča basin contributes greatly to the river discharge. The spring snowmelt brings water which has gained most of its DIC from atmospheric $\mathrm{CO}_{2}\left(\delta^{13} \mathrm{C}_{\mathrm{CO} 2}=-7.0 \%\right.$ ), from dissolution of carbonate rocks in the streambed $\left(\delta^{13} \mathrm{C}_{\text {calcite }}=\right.$ $+2.0 \%$ ), and from ground-water discharge into the river via springs which empty into the river along its course $\left(\delta^{13} \mathrm{C}_{\mathrm{DIC}}\right.$ between $-11 \%$ and $-15 \%$ ). In the late fall, the river receives most of its discharge from spring flows, and less from surface runoff. The springs issue water which is heavily influenced by soil $\mathrm{CO}_{2}$, and thus the carbon isotopic composition of the water is more negative. As the spring water is carried downstream in the river, it again begins to equilibrate with atmospheric $\mathrm{CO}_{2}$, and the carbon isotopic composition shifts toward more positive values as $\mathrm{CO}_{2}$ is lost and exchanged. Shifts in $\delta^{13} \mathrm{C}$ as much as $+0.4 \% / \mathrm{km}$ have been recorded (Urbanc et al., 1997). Therefore, by the time the Soča River reaches contact with the western edge of the Kras and begins to sink just south of Gorizia, it has $\delta^{13} \mathrm{C}_{\mathrm{DIC}}$ values between $-7.7 \%$ and $-12.0 \%$, with an annual mean of $-9.3 \%$.

In contrast to the river, local karst springs receive a greater portion of their recharge primarily infiltration of local precipitation into the karstified bedrock and typically show more depleted $\delta^{13} \mathrm{C}_{\mathrm{DIC}}$ ranges between -11.0 and $-15.0 \%$. The more negative values are the result of a greater influence of soil $\mathrm{CO}_{2}$ on the DIC in the water. The good separation between the carbon isotopic composition of the local ground-water and the Soča River water allows carbon isotopes to be useful for distinguishing between these two sources in the resurgent ground-waters of the Kras. Using both carbon and oxygen isotopes, Pezdič et al. (1986) estimated that as much as 50\% of the water pumped from the well at Klariči during dry periods comes from the Soča River. Thus, the carbon isotopes are a useful check on the interpretation of the other chemical and isotopic data obtained.

\section{WATER BALANCE OF THE KRAS REGION}

The boundaries of the Kras hydrogeologic system are well defined. There exists an impermeable flysch layer ( $>400 \mathrm{~m}$ in places) beneath the limestone bedrock. The limestone block is overthrust upon the flysch, which acts as a less permeable hydrogeologic barrier at depth. To the northwest, the limestone plateau slopes down to the plain of the Soča River. Here the karstified bedrock 
lies beneath a thick accumulation of alluvium, primarily sand and gravel-sized sediments.

To the southeast, the Reka River sinks completely, and is the major allogenic source of ground-water. The limestone rocks are again contacting flysch bedrock on the southeast edge. To the northeast, the valley of the Vipava River forms another boundary. This river flows also on flysch bedrock, however it loses a portion of its flow near the confluence with the Soča. To the southeast, the bedrock units of flysch and limestone are bounded by the Adriatic Sea.

The primary inputs of water into the system are:

1. precipitation on the Kras

2. the sinking of the Reka River

3. the Soča River sinking into its alluvial plain

4. the Vipava River sinking partially into its bed

5. the Raša River and other small sinks on the eastern edge of the Kras (ephemeral sources).

The thirty-year mean annual precipitation (19611990) values measured at several meterological stations across the Kras region is approximately $1400 \mathrm{~mm} / \mathrm{yr}$ (data from the Hydro-meteorological Survey of Slovenia). The surface area of the hydrologic basin delineated in Fig. 1 is approximately $440 \mathrm{~km}^{2}$, not including the allogenic drainage basin of the Reka River ${ }^{3}$. Much of the primary precipitation infiltrates directly into the aquifer due to thin soils and sparse vegetation (Krancj, 1997), however a mean value for annual evapotranspiration has been estimated to be as high as $45 \%$ of precipitation (Polli, 1971).

The flow of the Reka River has a minimum discharge of $0.16 \mathrm{~m}^{3} / \mathrm{sec}$, a maximum discharge of $387 \mathrm{~m}^{3} / \mathrm{sec}$, and an average discharge of $9.0 \mathrm{~m}^{3} / \mathrm{sec}$. The Reka River may contribute at most less than one-third of the Timavo springs total annual flow, and with an average baseflow of $1.0 \mathrm{~m}^{3} / \mathrm{sec}$, the Reka can contribute a maximum of $11 \%$ of the Timavo springs baseflow (Rojšek, 1996).

Losses of the Soča River to the Kras aquifer have been estimated at $20-25 \mathrm{~m}^{3} / \mathrm{sec}$ during high flow, and between $6-10 \mathrm{~m}^{3} / \mathrm{sec}$ during low flow (Morgante et al., 1966). Losses of the Vipava have been gaged at an average of $1.0 \mathrm{~m}^{3} / \mathrm{sec}$. Much of this water presumably mixes with the water of the alluvial aquifer supplied by the Soča River, and ultimately resurges at the major springs.
The primary outputs of the system are:

1. the Timavo spring group

2. Sardos spring

3. Moschenizze North and South springs

4. Lisert and Sablici springs

5. the springs of Doberdò polje

5. Aurisina spring

6. submarine springs along the Adriatic coastline (discharge unknown)

7. evapotranspiration

8. pumping ground-water for municipal use

All of the springs are artesian and perennial. The samples for the new data presented in this study were collected at the following locations:

Timavo: at the rise of the $1^{\text {st }}$ branch

Sardos: at the small canal across from the Roman ruins on the property of the Trieste Water and Gas Utility (A.C.E.G.A., Trieste)

Sablici: at Sablici canal where it passes beneath the highway

Doberdo': at the large blue-hole rise located on the northwestern end of the polje.

Moschenizze North: at the rise located on the property of A.C.E.G.A. Trieste.

Moschenizze South: along the spring run just below the source

Aurisina spring was not sampled during the study due to difficulty gaining access. The water from the springs of Doberdò polje drains through this polje, across another smaller polje (Pietrarossa polje) and eventually into Sablici canal. Thus the discharge of Sablici canal represents the final outlet of the upstream system that includes the springs of Doberdò and Pietrarossa poljes, as well as Sablici springs. Hereafter this flow will be collectively referred to as Sablici springs. After the construction of a new marina along the coast, the Lisert springs are now submerged, and their sampling is no longer possible.

Gemiti (1984a) estimated the average discharge of the major springs named above as follows:

\begin{tabular}{llr} 
Sablici + Lisert & $=$ & $2.2 \mathrm{~m}^{3} / \mathrm{sec}$ \\
Moschenizze + Sardos & $=$ & $2.4 \mathrm{~m}^{3} / \mathrm{sec}$ \\
Timavo & $=$ & $30.2 \mathrm{~m}^{3} / \mathrm{sec}$ \\
Aurisina & $=$ & $0.3 \mathrm{~m}^{3} / \mathrm{sec}$ \\
\hline Total outflow & $=$ & $35.1 \mathrm{~m}^{3} / \mathrm{sec}$
\end{tabular}

\footnotetext{
${ }^{3}$ Other published estimates of the Kras aquifer recharge area vary between $763 \mathrm{~km}^{2}$ (Civita et al., 1995) to $1000 \mathrm{~km}^{2}$ (Mosetti, 1966). These include areas of both autogenic and allogenic recharge in the estimate. The total allogenic recharge area has not yet been welldefined, therefore only the surface area for autogenic recharge is reported here, and the estimate of $440 \mathrm{~km}^{2}$ from Kranjc (1997) is used.
} 
Using these values, Civita et al. (1995) presented an accounting of the water balance of the region and calculated a $10 \%$ difference between inputs and outputs, with more recharge than discharge. These authors concluded that a satisfactory water balance had been attained. However, their estimate did not account for 1) losses due to evapotranspiration, 2) allogenic contributions from the Soča River, 3) contributions from the ephemeral Raša River and other nearby sinking ephemeral streams along the northeastern border of the Kras, 4) outflow of the submarine springs along the coastline, and 5) pumping by water supply wells. Thus, the water balance needs to be re-evaluated, and should include measured or quantified estimates of the missing quantities.

The water tracing work and the hydrologic mass balance research previously conducted on the region indicate the following:

1) The boundaries of the system have for the most part been well-defined, however a complete water balance has yet to be constructed, mainly due to ungaged submarine spring outflow.

2) The Reka River significantly contributes to the Timavo discharge only under flood conditions, and for brief durations (several days to a few weeks).

3) The majority of the baseflow of the Timavo springs is supplied by a source hypothesized to be the Soča River.

In the conclusion of his book, Timavo: Esplorazioni e Studi Galli (1999) wrote:

"After five hundred years of study, the hydrogeologic system of the Timavo is sufficiently known in its general characteristics (coexistence and interactions of conduit drainages and diffuse drainages), and in the complex relations of water fed by various catchment basins-both karstic and fluvial-that are discharged through its resurgence zone. Important unknowns, however, still await an answer, such as the quantitative determination of different discharge contributions through alternating seasonal hydrological cycles and during the baseflow and flood regimes, the determination of the storage capacity of the karst massif, the delineation of the recharge basin and of mixing between various reservoirs, and the determination of the course of principle drainage."

The original work described in part II of this paper was initiated prior to Galli's book being published; however, the goals of this research were aimed toward providing answers to some of his "unknowns", specifically:

1) To test the hypothesis that the Soča-Vipava sinking zone contributes a large proportion of water to the discharge of the karst resurgence zone during dry periods, while during wet periods the resurgence is fed more by local precipitation.

2) To quantify volumes of storage in the karst aquifer based on recession analysis of the Timavo spring discharge, and to relate chemistry with flow regimes in order to distinguish the sources of water contributing to the discharge in those flow regimes.

3) To estimate the transit time of the Soča River water to the springs and wells of the Kras resurgence zone based on measured isotopic tracers.

\section{RESULTS OF A TWO-YEAR STUDY OF THE KRAS HYDROGEOLOGY USING NATU- RAL CHEMISTRY AND ISOTOPES AS TRACERS}

Water samples from the major recharge and discharge points of the Kras aquifer were collected twice per month during the years 1999-2000, and more frequently (at least daily) during large storm events in October, 2000. The approach taken in this work was to first define the flow regimes of the aquifer resurgence, then to examine the chemical variability within each of the flow regimes. Focused sampling was conducted during storm events to examine short-term changes in the chemical composition of the aquifer discharge. Details of the design, methods, and selected results of the study are presented in Doctor (2002), Doctor and Alexander (2005), and Doc- tor et al. (2006). Here, a summary of the major findings is presented.

\section{DETERMINATION OF AQUIFER FLOW REGIMES AND STORAGE VOLUMES OF THE TIMAVO SPRINGS}

In order to quantitatively define the flow regimes considered here, a hydrograph analysis of the Timavo springs discharge was performed. Six years of discharge records were available, from 1995-2000. From the six-year record, six of the larger recession periods were chosen. The re- 
cession flows at the Timavo springs were fit by a series of linear segments through ordinary linear regression in semi-log space (Fig 4a). The simple exponential decay relation (Maillet, 1905) provides an adequate model for the analysis of all discharge regimes at the springs. From the hydrograph recession analysis, a Master Recession Curve (MRC) was constructed by averaging the recession coefficients $(\alpha)$ and initial discharge $\left(q_{0}\right)$ of the longest individual event recessions from the long-term discharge records of the Timavo springs. Four distinct segments to the Timavo MRC were identified, each corresponding to a characteristic flow regime. The breaks in slope define the discharge limits of each flow regime. The in-

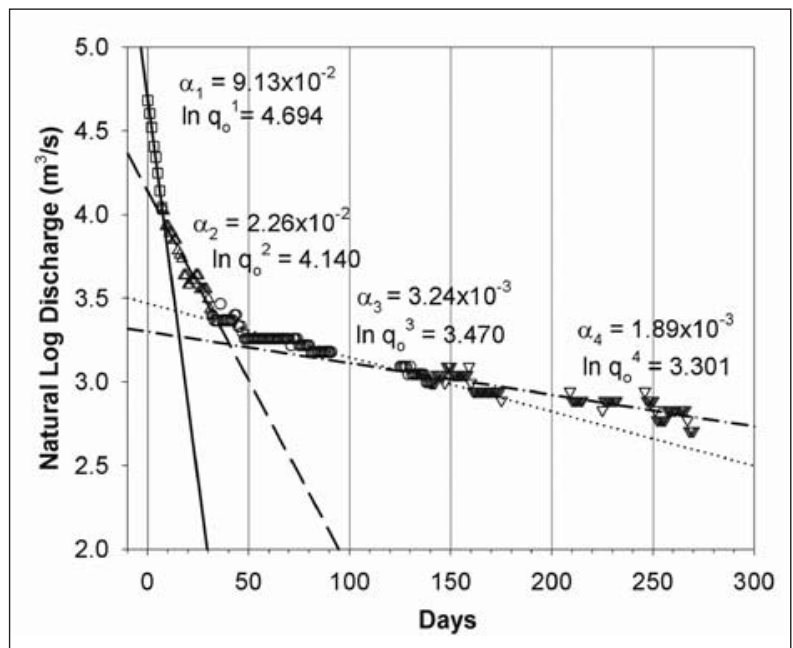

(a)

Fig.4: (a)Representative recession segments from long-term recession in 1999, and (b) master recession curve compiled from 6 long term recession curves of the Timavo springs(1995-2000).

tersections between these recession segments were used to delimit four flow regimes of the Kras aquifer outflow: (1) flood flow, (2) high flow (3) moderate flow, and (4) baseflow. The flood flow regime exists at discharges of the Timavo above $50 \mathrm{~m}^{3} / \mathrm{s}\left( \pm 5 \mathrm{~m}^{3} / \mathrm{sec}\right)$, high flow is between 30 and $50 \mathrm{~m}^{3} / \mathrm{s}$, moderate flow is between 15 and $30 \mathrm{~m}^{3} / \mathrm{s}$, and baseflow discharge is below $15 \mathrm{~m}^{3} / \mathrm{s}$ (Fig. $4 \mathrm{~b}$ ).

The total recession volume of the Timavo springs was estimated by integrating across the entire MRC, from flood flow to baseflow (up to 10,000 days), and is approximately 585 million $\mathrm{m}^{3}$ (Doctor and Alexander, 2005). Storage volumes of individual recession segments were also estimated by integrating across each segment and subtracting the volumes of the lower flow regimes across the same time interval. From this analysis, $88.5 \%$ is estimated to be from the baseflow regime, about 518 million $\mathrm{m}^{3}$ (Table 2). For comparison, Civita et al. (1995) estimated the average annual outflow of the Timavo springs to be 952.4 million $\mathrm{m}^{3} / \mathrm{yr}$, or a volume 1.8 times as great as the baseflow storage volume estimated by the hydrograph recession. According to the karst aquifer classification proposed by El-Hakim and Bakalowicz (2007), the Timavo springs would fall into category 4 , having a large regulating capacity $\mathrm{k}$ of 0.54 . This category of karst aquifer is described as having a "well-karstified infiltration zone and an extended conduit network ending in flooded phreatic zone" (El-Hakim and Bakalowicz, 2007). This is a fitting description of the Kras aquifer.

Although the Timavo springs drain a distinct flow system from the other springs in the resurgence zone, it is assumed that the flow regimes at the Timavo springs

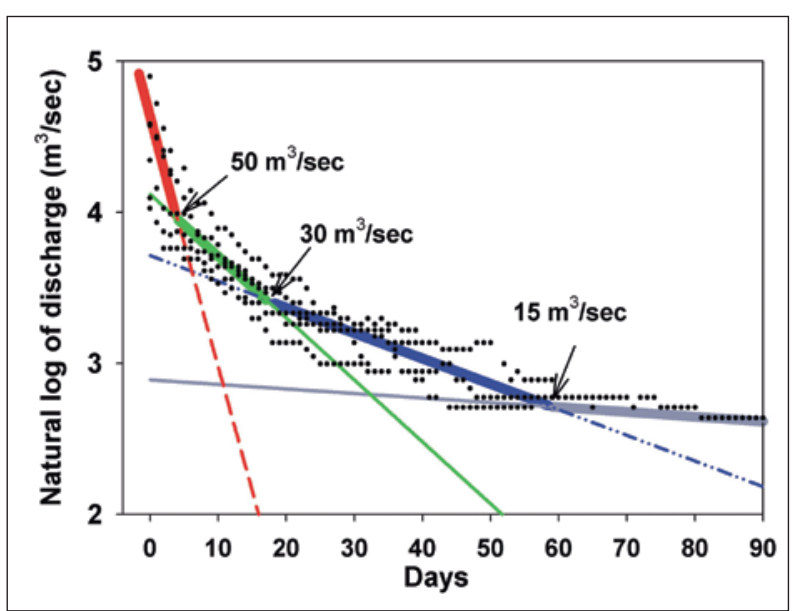

(b) serve as an adequate proxy for the flow regimes of the local aquifer resurgence zone as a whole due to the predominant hydraulic connection through the phreatic artesian aquifer.

\section{GEOCHEMICAL AND ISOTOPIC CHARACTERIZATION OF THE KRAS AQUIFER RESURGENCE ZONE}

Figure 5a shows the oxygen and dissolved inorganic carbon (DIC) isotope compositions of Sardos spring, Timavo spring ( $1 \mathrm{~s}^{\mathrm{t}}$ branch) and Well B-4, with the possible end-member sources of the Soča River, Reka River, and well B-3 also plotted. Most of the spring and well samples fall within the range of the Soča River and well B-3 endmembers, while the Reka River is not a distinct end-member source for most of the samples; however, the carbon isotopes are not perfectly conservative tracers, therefore 


\begin{tabular}{|c|c|c|c|c|c|c|c|}
\hline $\begin{array}{l}\text { Recession } \\
\text { segment }\end{array}$ & Flow regime & $\begin{array}{c}\text { Discharge range } \\
\left(\mathrm{m}^{3} / \mathrm{sec}\right)\end{array}$ & $\begin{array}{c}a \\
\left(\text { day }^{1}\right)\end{array}$ & $\begin{array}{c}q_{o} \\
\left(m^{3} / s\right)\end{array}$ & $\begin{array}{c}\text { Recession Period } \\
\text { (days) }\end{array}$ & $\begin{array}{c}\text { Storage } \\
\text { volume }\left(m^{3}\right)\end{array}$ & $\begin{array}{c}\text { \% of total } \\
\text { storage }\end{array}$ \\
\hline 1 & Flood flow & $>50$ & $\begin{array}{c}1.64 x \\
10-1\end{array}$ & 101 & 0 (peak Q) - 4 & $0.06 \times 108$ & $1.0 \%$ \\
\hline 2 & High flow & 30 to 50 & $\begin{array}{c}4.10 x \\
10-2 \\
\end{array}$ & 62 & $4-17$ & $0.13 \times 108$ & $2.2 \%$ \\
\hline 3 & Moderate flow & 15 to 30 & $\begin{array}{c}1.70 x \\
10-2\end{array}$ & 41 & $17-58$ & $0.48 \times 108$ & $8.2 \%$ \\
\hline \multirow[t]{2}{*}{4} & Baseflow & $<15$ & $\begin{array}{c}3.00 x \\
10-3\end{array}$ & 18 & $58->10,000$ & $5.18 \times 108$ & $88.5 \%$ \\
\hline & & & & & Total: & $5.85 \times 108$ & $100 \%$ \\
\hline
\end{tabular}

Tab. 2. Storage volumes estimated from recession analysis of the Timavo springs

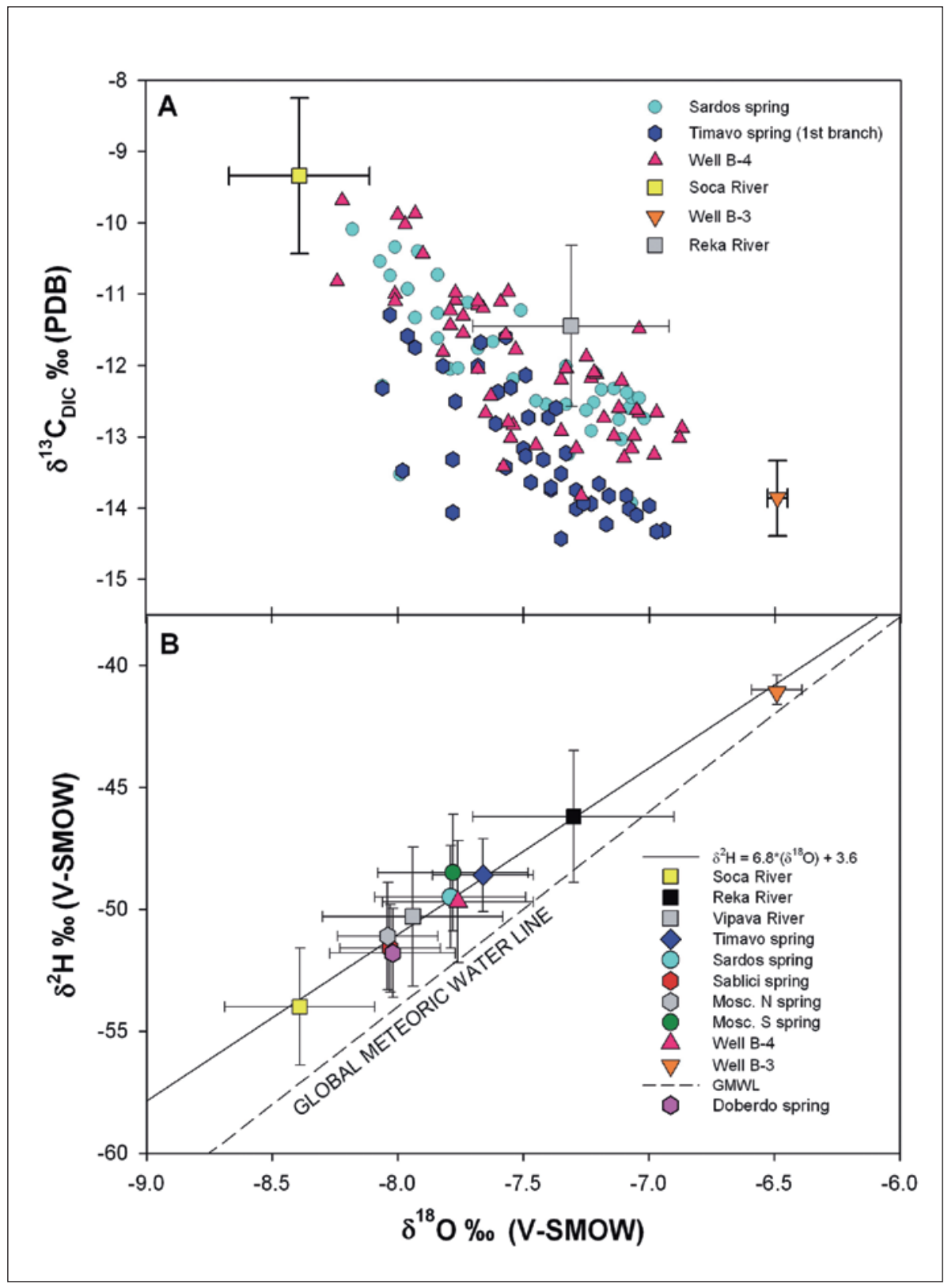

the interpretation is limited. Figure $5 \mathrm{~b}$ shows the average stable oxygen and hydrogen isotopic compositions of the waters of the resurgence zone plotted along with the Global Meteoric Water Line (GMWL). The mean oxygen isotope composition of this well $(-6.5 \%)$ is nearly equivalent to the value of weighted mean annual rainfall $(-6.4 \% 0)$ measured at the Sela na Krasu meterological station during the study period. Thus, well B-3 serves as a good indicator of the integrated autogenic recharge on the karst.

When viewed in times series, the results of the isotopic sampling show a repetitive pattern: during recharge events, the $\delta^{18} \mathrm{O}$ compositions shift toward higher val-

Fig. 5. Panel A: $\delta^{18} \mathrm{O}$ versus $\delta^{13} C_{D I C}$ isotope values of selected waters. Panel B: Average oxygen and hydrogen stable isotopic compositions of all Kras waters sampled. Ranges of the measured compositions are shown with the vertical and horizontal bars. A linear least-squares regression through the mean ground water data is provided, and the Global Meteoric Water Line (GMWL) is shown for reference. 


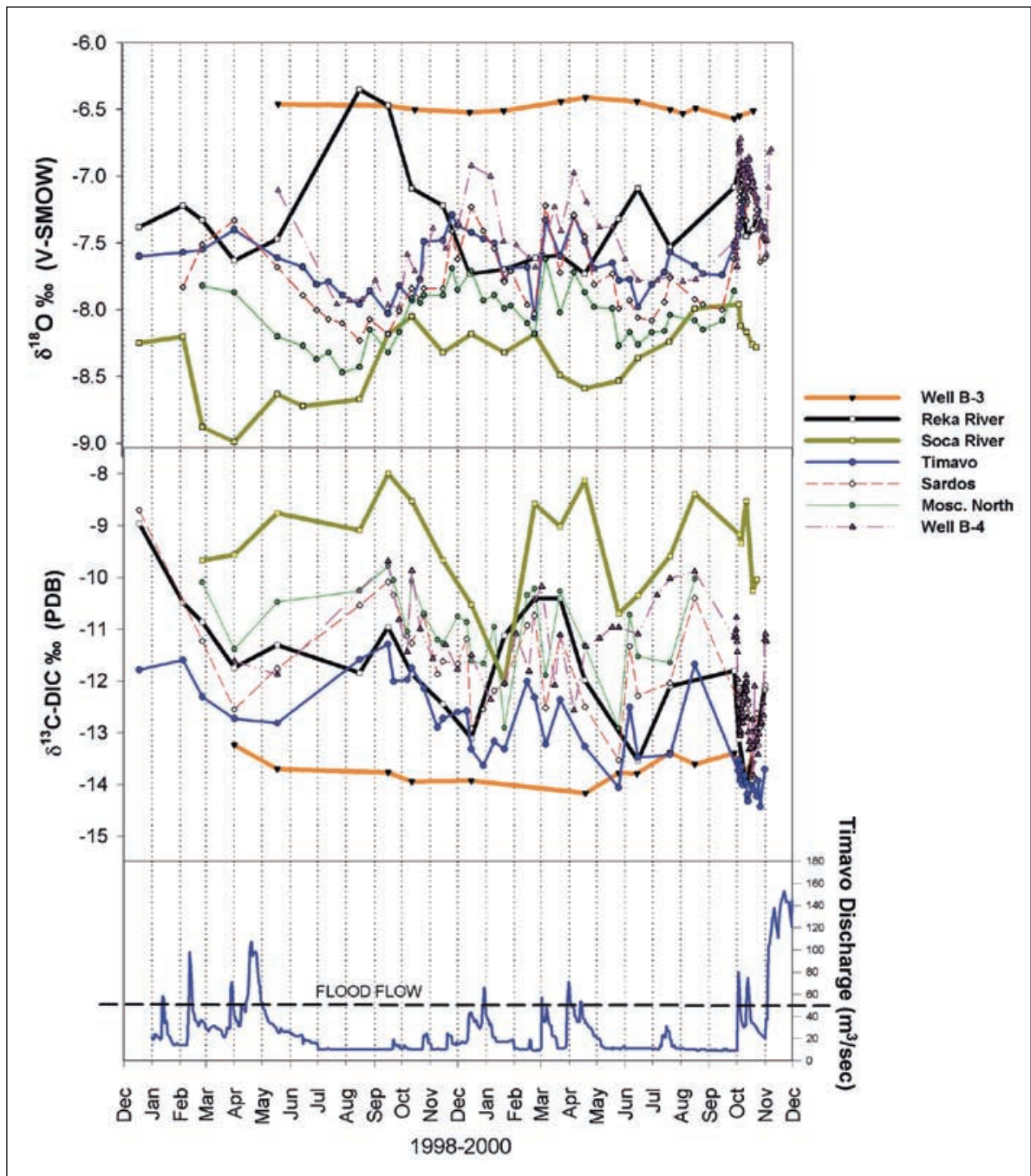

Fig. 6: Oxygen $\left(\delta^{18} \mathrm{O}\right)$ and carbon $\left(\delta^{13} C_{D I C}\right)$ isotope record of selected sampling points during the study period. Note that the compositions of the well B-3 and the Soča River bracket the compositions of the major springs and the well B-4. Discharge of the Timavo Springs is provided for reference. The dashed line indicates the limit of the flood flow regime at $50 \mathrm{~m}^{3} / \mathrm{sec}$. which do not have a connection to the Reka River, therefore is it likely that the seasonal variability of all the springs is controlled by mixing between similar sources but in different proportion for each spring. For example, Moschenizze North spring shows the lowest $\delta^{18} \mathrm{O}$ values throughout the year, indicating a greater proportion of water derived from the Soča River than the other springs. In contrast, Timavo shows the lowest $\delta^{13} \mathrm{C}_{\mathrm{DIC}}$ values throughout the year, indicating a greater overall contribution from the autogenic recharge component than the other springs (represented by well B-3). The frequency of sampling during most of the study period was too coarse (monthly to bi-weekly) to closely evaluate all individual storm events; however, samples collected during the storm events of October 2000 were collected at a higher frequency. These results will be discussed later.

In addition to the oxygen and carbon isotopes, $\mathrm{Ca}^{2+}, \mathrm{Mg}^{2+}, \mathrm{Cl}^{-}$, temperature, $\mathrm{pH}$, total DIC, and specific conductance were measured on these samples (Doctor, ues while the $\delta^{13} \mathrm{C}$-DIC compositions shift toward lower values. The Soča River and well B-3 values bracket the compositions of the major springs and well B-4 throughout the study period. Taking the Soča River and well B3 compositions as end-member sources, the source of aquifer outflow shifts from water derived from the Soča River toward water derived from autogenic recharge on the Kras plateau during recharge events (Fig. 6). In spite of the known connection between the Reka River and the Timavo springs, the data do not indicate that the Reka River controls the long-term seasonal variability in the composition of the Timavo springs; however, the Reka River may significantly influence the Timavo springs during flood flow events. The Timavo variability is similar to that of the other springs of the resurgence zone
2002). Although the results are not shown here, a twocomponent mixing model is not sufficient to explain all of the variability. However, the data can in most cases be completely circumscribed by a model employing the following three end-members:

1. Well B-3("karst water")

2. Soča River water

3. a high $\mathrm{Cl}$ component

According to the chemistry data, the most distinguishing factor of the third end-member is a higher chloride concentration. This end-member is inferred to be a sub-component of the "karst water" end-member that is chemically conditioned by a source of contamina- 


\begin{tabular}{|c|c|c|c|c|}
\hline \multirow[t]{2}{*}{ Spring } & \multirow[t]{2}{*}{ Flow Regime } & \multicolumn{3}{|c|}{ Calculated End-member proportions } \\
\hline & & Soča River & Karst water & Anthropogenic Component \\
\hline \multirow[t]{3}{*}{ Sardos } & Low flow & $72 \%$ & $20 \%$ & $8 \%$ \\
\hline & Mean flow & $76 \%$ & $16 \%$ & $8 \%$ \\
\hline & High flow & $53 \%$ & $35 \%$ & $12 \%$ \\
\hline \multirow[t]{3}{*}{ Mosc. South } & Low flow & $72 \%$ & $20 \%$ & $8 \%$ \\
\hline & Mean flow & $63 \%$ & $26 \%$ & $11 \%$ \\
\hline & High flow & $51 \%$ & $34 \%$ & $15 \%$ \\
\hline \multirow[t]{3}{*}{ Mosc. North } & Low flow & $88 \%$ & $3 \%$ & $10 \%$ \\
\hline & Mean flow & $77 \%$ & $10 \%$ & $13 \%$ \\
\hline & High flow & $74 \%$ & $12 \%$ & $14 \%$ \\
\hline \multirow[t]{3}{*}{ Doberdo' } & Low flow & $85 \%$ & $12 \%$ & $2 \%$ \\
\hline & Mean flow & $81 \%$ & $11 \%$ & $7 \%$ \\
\hline & High flow & $76 \%$ & $16 \%$ & $8 \%$ \\
\hline \multirow[t]{3}{*}{ Sablici } & Low flow & $88 \%$ & $9 \%$ & $4 \%$ \\
\hline & Mean flow & $82 \%$ & $8 \%$ & $10 \%$ \\
\hline & High flow & $78 \%$ & $8 \%$ & $15 \%$ \\
\hline \multirow[t]{3}{*}{ Timavo } & Low flow & $57 \%$ & $38 \%$ & $5 \%$ \\
\hline & Mean flow & $53 \%$ & $40 \%$ & $6 \%$ \\
\hline & High flow* & $49 \%$ & $44 \%$ & $7 \%$ \\
\hline
\end{tabular}

${ }^{\star}$ Excludes data from the flood flow periods, i.e. discharge greater than $50 \mathrm{~m}^{3} / \mathrm{sec}$

Tab. 3: Estimated mixing proportions of end-members in Kras ground-waters from the PCA/EMMA model using $\mathrm{Mg}, \mathrm{Ca}, \mathrm{Cl}, \mathrm{SO}$, $\delta^{18} \mathrm{OH}_{2} \mathrm{O}, \delta^{13} \mathrm{C}_{\mathrm{DIC}}$.

tion. Water from nearby caves in the region (the Cave East of the Train Station in Monfalcone and the Timavo Fishpond Cave) exhibit higher chloride concentrations than the other ground-waters, and may be indicative of the chloride source. Despite the proximity of these caves to the sea, the water chemistry is not consistent with a seawater source. The high-chloride concentrations are likely to be the result of the impact of anthropogenic activities on the ground-water. It is known that caves in the region near to the Klariči pumping station were once used for military storage, and may be a possible source of the contamination (F. Šušteršič, personal communication, 2007). Although the high-chloride source water was never directly sampled in this study, the water sample with the highest measured chloride was that collected from the Timavo Fishpond Cave (Gemiti, 1994), thus its composition was presumed to be indicative of the third end-member.

The chemical and isotopic data for each spring and well were grouped according to the flow regime in which they were collected across the two years of sampling, and principal components analysis (PCA) was performed on the data. High flow and flood flow were combined into a single flow regime ("High flow") since very few data were collected during flood flow conditions. Subsequently, end-member mixing analysis (EMMA) was performed using the compositions of the end-members listed above (see Doctor et al., 2006 for details on the method). The results are presented in Table 3 . The Timavo springs were treated differently in this analysis because the Reka River was not considered as an end-member in the model. Therefore, any chemical and isotopic data obtained during periods of flood flow (greater than $50 \mathrm{~m}^{3} / \mathrm{sec}$ ) at $\mathrm{Ti}$ mavo were excluded to remove periods during which the Reka River may have had a dominant influence. Contributions to Timavo from the Reka River are in general difficult to separate using this approach given the lack of a distinct end-member composition to the Reka River (e.g., see Fig. 5). Therefore, under lower flow regimes it is assumed that contributions from the Reka River are contained within the proportion of the "karst water" component estimated for Timavo. This is likely given that the subterranean flowpath enters the phreatic portion of the aquifer downstream of Trebiciano shaft, and the composition of the Reka River measured upstream would likely be masked by mixing with water in phreatic storage. Considering the results of previous quantitative tracer tests, the Reka contribution would probably not exceed $20 \%$ under the majority of flow conditions, except flood flow (Fig. 3).

According to this analysis, water from the Soča River provides the largest component of flow to the resurgence zone springs under all flow regimes. The other major proportion is from the "karst water" end-mem- 


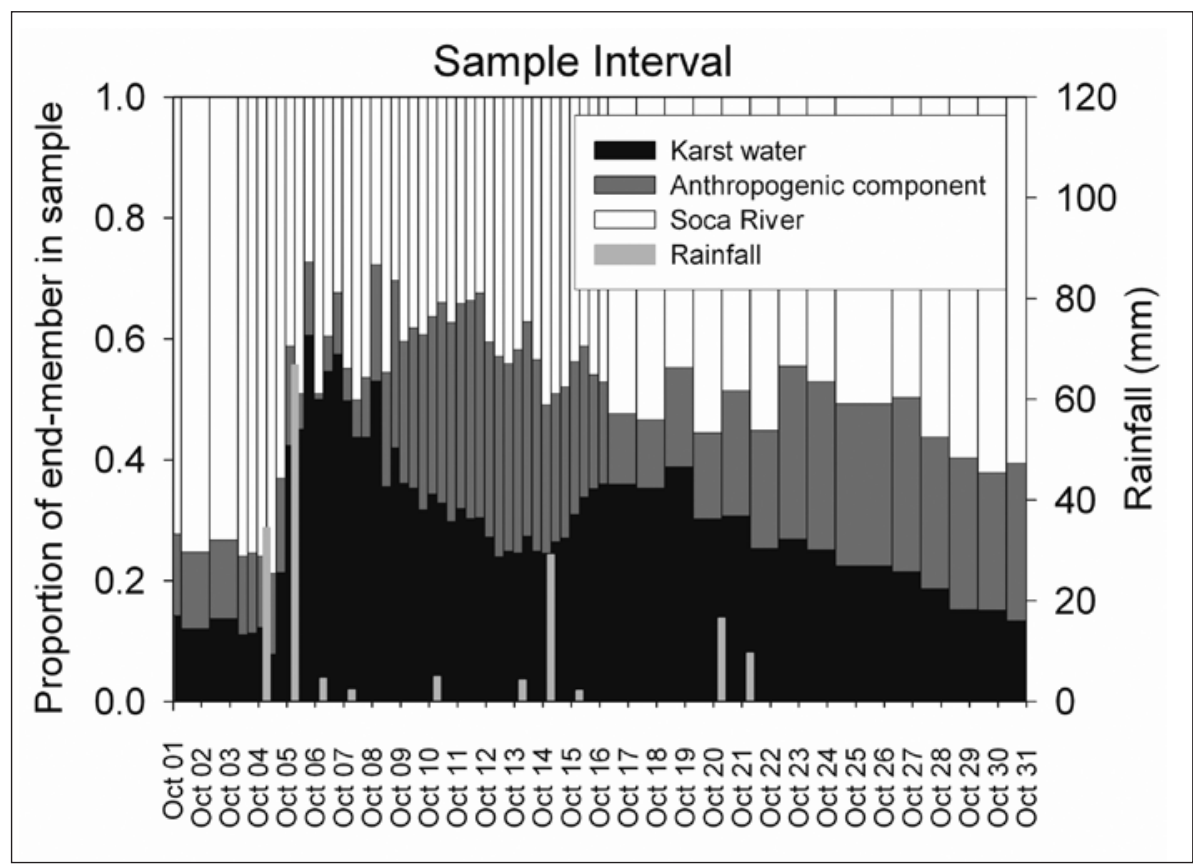

Fig. 7: Changing proportions of aquifer components at the water supply well B-4 during storm events of October 2000 (from Doctor et al., 2006).

ber represented by well B-3, with relatively minor contributions from the high $\mathrm{Cl}$ - component. The greatest change in proportions of end-members occurs at high flow, when the contributions from well B-3 and from the high Cl- end-members increase as the Soča proportion decreases. The Sardos/Moschenizze South and the Sablici/Doberdò/Moschenizze North spring groups show similar proportions of each end-member for each flow regime. The proportion of Soča River water is greatest in the Sablici/Doberdò/Moschenizze North group, ranging from $74 \%$ at high flow to $88 \%$ at low flow. Within this group, only Moschenizze North and Sablici show significant impact from the anthropogenic component endmember (up to $15 \%$ ), while Doberdò shows a maximum proportion of anthropogenic component water of $8 \%$ at high flow. The Sardos/Moschenizze South springs show a much higher proportion of "karst water" across all flow regimes than the Sablici/Doberdò/Moschenizze North group. This indicates that more of the Sardos/Moschenizze flow is supplied by autogenic recharge water, whereas the Sablici/Doberdò/Moschenizze North springs are fed primarily by water from the Soča River flowing through the phreatic zone.

Well B-4 stands apart from all of the other groundwaters. It exhibits the greatest variation among proportions of Soča River and karst water with changing flow regime. At low flow, nearly $75 \%$ of the water is supplied by the Soča River, with the remaining $25 \%$ split evenly between the high $\mathrm{Cl}^{-}$component and karst water end- members. This proportion changes rapidly during storm events, with the Soča River component replaced by an increasing proportion of karst water with rising head level, followed by subsequent replacement of the karst water by the high $\mathrm{Cl}^{-}$component during water level recession (Fig. 7). This progression repeats with additional rainfall, however the high $\mathrm{Cl}^{-}$component eventually dominates the well chemistry at the highest water levels (Doctor et al., 2006).

Using the results of the PCA/EMMA analysis, it was possible to calculate the proportions of each of the three end-members in the average gaged outflow of the resurgence zone by multiplying the average proportion of each component estimated for each of the springs by their average discharge and summing (Table 4). In summary, the Soča River provides approximately $56.3 \%$ of the total gaged outflow of the Kras aquifer resurgence under average flow conditions; this represents a discharge of $19.8 \mathrm{~m}^{3} / \mathrm{sec}$, a value that is nearly equivalent to the losses of the Soča River $\left(20 \mathrm{~m}^{3} /\right.$ sec) gaged downstream of the city of Gorizia (Mosetti \& D'Ambrosi, 1963). The proportion of Soča River water in the outflow at the major resurgent springs slightly increases at low flow and decreases at high flow. The unimpaired karst water, or stored autogenic recharge, provides $36.3 \%$ of the outflow under average flow conditions. The impaired autogenic recharge, or anthropogenic component, contributes approximately $7.4 \%$ of the outflow water.

In light of these results, the previous water balance calculation for the Kras aquifer by Civita et al. (1995) seemed to have underestimated the contribution of the Soča River component. Although the Soča River contribution to the Kras aquifer outflow has been quantitatively estimated in this study, both evapotranspiration as well as the combined discharge of the submarine springs along the Adriatic coast have yet to be adequately estimated and probably represent significant components of the overall water balance. Therefore, a complete water balance for the Kras aquifer awaits quantification of these two components. 


\begin{tabular}{|c|c|c|c|c|c|c|c|}
\hline \multirow[t]{2}{*}{ Water Source: } & \multirow[t]{2}{*}{$\begin{array}{l}\text { Mean Flow } \\
\text { (m3/sec): }\end{array}$} & \multicolumn{3}{|c|}{$\begin{array}{l}\text { Estimated proportion of End- } \\
\text { members in the outflow: }\end{array}$} & \multicolumn{3}{|c|}{$\begin{array}{l}\text { Quantity of discharge apportioned } \\
\text { to each end-member }\left(\mathrm{m}^{3} / \mathrm{sec}\right) \text { : }\end{array}$} \\
\hline & & $\begin{array}{l}\text { Soča } \\
\text { River }\end{array}$ & $\begin{array}{l}\text { Karst } \\
\text { Water }\end{array}$ & $\begin{array}{l}\text { Anthropogenic } \\
\text { Component }\end{array}$ & $\begin{array}{l}\text { Soča } \\
\text { River }\end{array}$ & $\begin{array}{l}\text { Karst } \\
\text { Water }\end{array}$ & $\begin{array}{l}\text { Anthropogenic } \\
\text { Component }\end{array}$ \\
\hline Timavo & 30 & $53 \%$ & $40 \%$ & $7 \%$ & 15.9 & 12.0 & 2.1 \\
\hline Mosc. South + Sardos & 2.0 & $70 \%$ & $21 \%$ & $9 \%$ & 1.4 & 0.42 & 0.18 \\
\hline Sablici + Mosc. North + Lisert & 3.0 & $80 \%$ & $10 \%$ & $10 \%$ & 2.4 & 0.30 & 0.30 \\
\hline Well B-4 & 0.1 & $60 \%$ & $12 \%$ & $28 \%$ & 0.06 & .012 & .028 \\
\hline TOTAL: & 35.1 & & & & 19.8 & 12.7 & 2.6 \\
\hline \multicolumn{5}{|c|}{ TOTAL PROPORTION: } & $56.3 \%$ & $36.3 \%$ & $7.4 \%$ \\
\hline
\end{tabular}

Tab. 4: Quantification of end-member proportions in Kras aquifer outflow under average flow conditions.

\section{DYNAMIC CHANGES IN AQUIFER OUTFLOW DURING STORM EVENTS}

A detailed analysis of changing source contributions to the water supply well B-4 at Klariči during storm events of October 2000 was presented by Doctor et al. (2006). Here, the results of the Timavo springs and Sardos springs sampled during the same storm events are presented. Sampling at the Timavo and Sardos springs was not as frequent as at the well B-4, thus the records at these springs are not as detailed. Nonetheless, important trends can be identified in the data. The results of the storm event sampling at Timavo are presented graphically in Fig. 8 and Fig. 9. Two distinct peaks in the Timavo springs discharge are evident; the first occurred after the rain event of Oct 1-2, and the second resulted from the rain that fell from Oct 10-12.

Based upon the $\delta^{18} \mathrm{O}$ values, the waters of the Timavo springs, Sardos spring, and the well B-4 share a similar source under low flow, but diverge during recharge events (Fig. 8). Sardos spring and well B-4 respond more rapidly to storm pulses than the Timavo springs, and likely gain the majority of their flow from the shallow epiphreatic aquifer, while the Timavo springs are supplied by deeper, phreatic flow paths and respond more gradually to rainfall events.

A dominant influence of the Reka River was not obviously observed at the Timavo springs during the storm events of October 2000 (Fig. 9). However, the trends in the data obtained show that the overall $\delta^{18} \mathrm{O}$ composition of the Timavo springs shifted toward that of the well B-3, or "karst water" during the first storm event (from Oct. 2 to Oct. 12), then gradually shifted to lower values that may have approached the composition of the Reka River later in the recession period. Alternatively, the shifts could have been related to mixing between a Soča River component and the well B-3 component.

Based upon prior tracing tests, the transit time of Reka River water to the Timavo springs for a flood of this magnitude would likely have been on the order of several days. It is interesting that as the Reka River $\delta^{18} \mathrm{O}$ composition abruptly decreased, the Timavo composition continued a steady increasing trend (Fig. 9). The longer than expected lag time in the isotopic response may be the result of the storm events having occurred after a prolonged dry period. This indicates that the Reka River, although constantly sinking into the aquifer of the Kras, does not contribute significantly to the flow of the Timavo springs in the lower flow regimes, in spite of the rapid transit time of the river water to the springs during floods.

\section{TRANSIT TIME ESTIMATION OF SOČA RIVER WATER TO THE KRAS RESURGENCE ZONE}

Cross-correlation time series analysis was performed on the monthly $\delta^{18} \mathrm{O}$ values of the Soča River and those of the Timavo springs, Sardos spring, and the pumping well at Klariči from 1984-1988 and from 1998-2000 (Fig.10). The requirements for cross correlation of time series are that: (1) the series must be a continuous set of data taken in equal time increments (daily, weekly, monthly, etc.); (2) no missing values are allowable for any given portion of the series; (3) trends in the data set may be removed; and (4) the data must be standardized. The first requirement was difficult to meet with the raw $\delta^{18} \mathrm{O}$ data that were available. First, two separate time series exist-the data published by Flora and Longinelli (1989) and Pezdič et al. (1986) collected between 1985-1988, and the data generated between 1998-2000 by Doctor (2002). Thus, each data set was analysed separately, and the results compared.

The most complete set of data for both periods exists at the monthly time interval, therefore this analysis was conducted using monthly data. However, due to the vagaries of field work water samples were not all collected at equal time intervals (number of days), nor at all places on the same day in any given month. Thus, in order to 


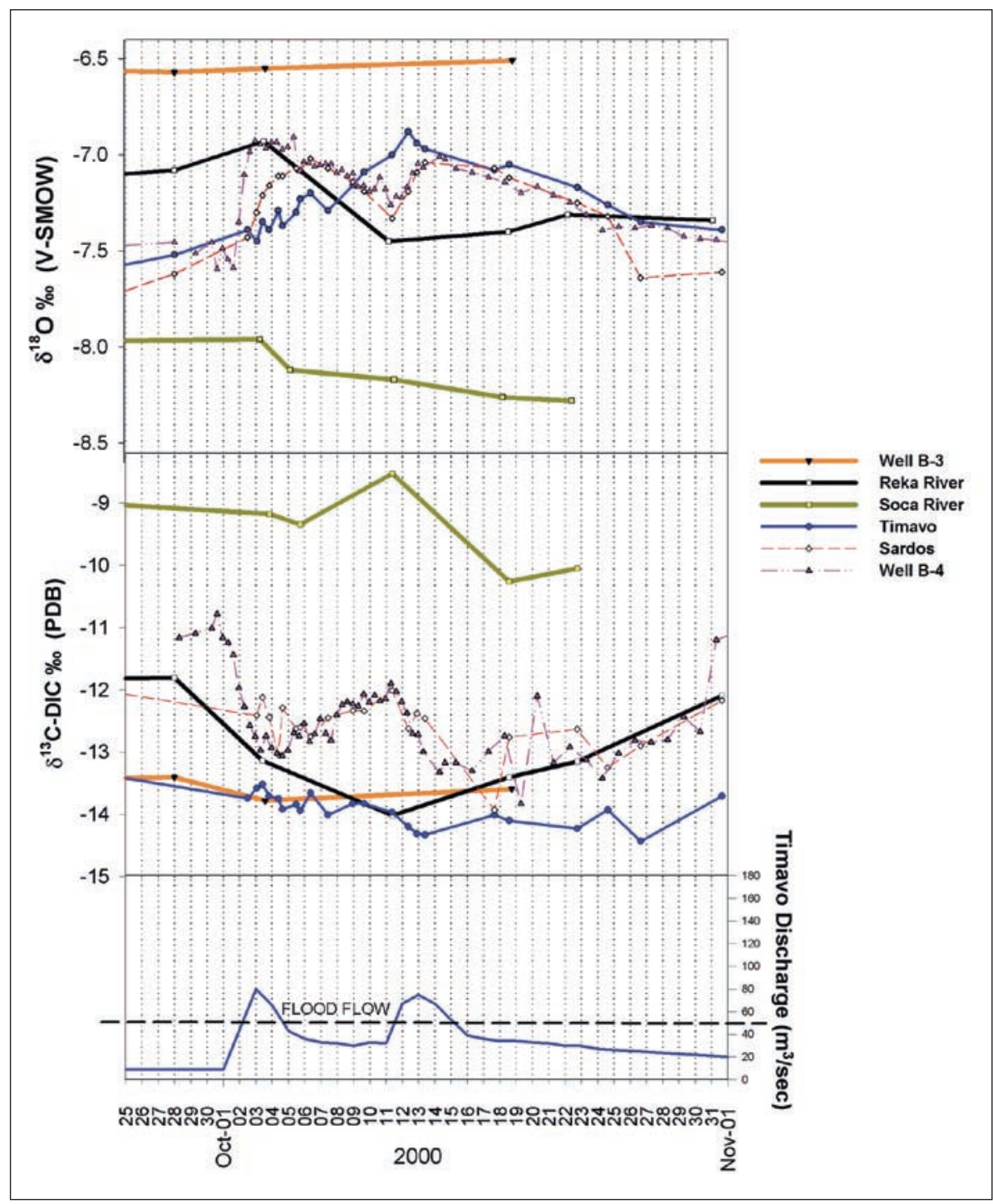

Fig. 8: Oxygen $\left(\delta^{18} \mathrm{O}\right)$ and carbon $\left(\delta^{13} \mathrm{C}_{\mathrm{DIC}}\right)$ isotope record of selected sampling points during storm events, October 2000. Discharge of the Timavo springs is provided for reference.

flood events, and even then only for a relatively short duration (from several days up to three weeks). The method here was examining monthly trends over years; therefore, the Reka River time series was not included in this analysis.

For the $\delta^{18} \mathrm{O}$ isotopic time series examined here, both linear and periodic trends are evident, however only the linear trends were removed. This was accomplished through isolation of the trend by a least-squares regression, and subsequent subtraction of the trend from each time series. The data were standardized according to the method of conversion to $\mathrm{z}$-scores by subtracting the sample mean and dividing by the sample standard deviation, such that the mean of the $z$-score series is 0 and the standard deviation is 1.0.

The gaged losses of the Soča River $\left(\sim 20 \mathrm{~m}^{3} / \mathrm{sec}\right)$ are significant enough to shift the isotopic compositions of the springs, whose average combined discharge is approximately $32 \mathrm{~m}^{3} / \mathrm{sec}$. The cross-correlations of the $\delta^{18} \mathrm{O}$ time series have shown that the transit time of the Soča River water to the Timavo and Sardos springs and well

complete the time series, monthly means were computed to account for multiple data collected during the same month in different years (i.e., all $\delta^{18} \mathrm{O}$ measurements of samples taken during any single month were averaged and the result used as the value for that month). For a series that was lacking in data over two or more successive months, that series was terminated at the point where the interruption occurred. For a series that lacked a month's worth of data between data from a preceding and following month, the missing value was estimated by taking the average of the two values immediately preceding and following that month. In this way, the overall structure of the data was preserved. The Reka River is apparently of significance in affecting the Timavo springs only during
B-4 is on the order of 1-2 months. The relative transit time of the river water to each of the resurgence points is on the order of $\leq 1$ month to the Timavo springs, 1-2 months to Sardos, and 2 months to the well at Klariči. Thus, Timavo is affected by Soča River water faster than the other two sampling points. This would indicate that there exists a deep, well integrated conduit network that extends beneath the Sardos and Well B-4 conduits, but is nonetheless connected to them by less-transmissive pathways. This is in accordance with the aquatic speleological exploration of the Timavo springs. The main spring branch has been dived to a depth of $82 \mathrm{~m}$ below sea level, and the divers discovered a very large room, the dimensions of which were never completely determined (Guglia, 1994). 


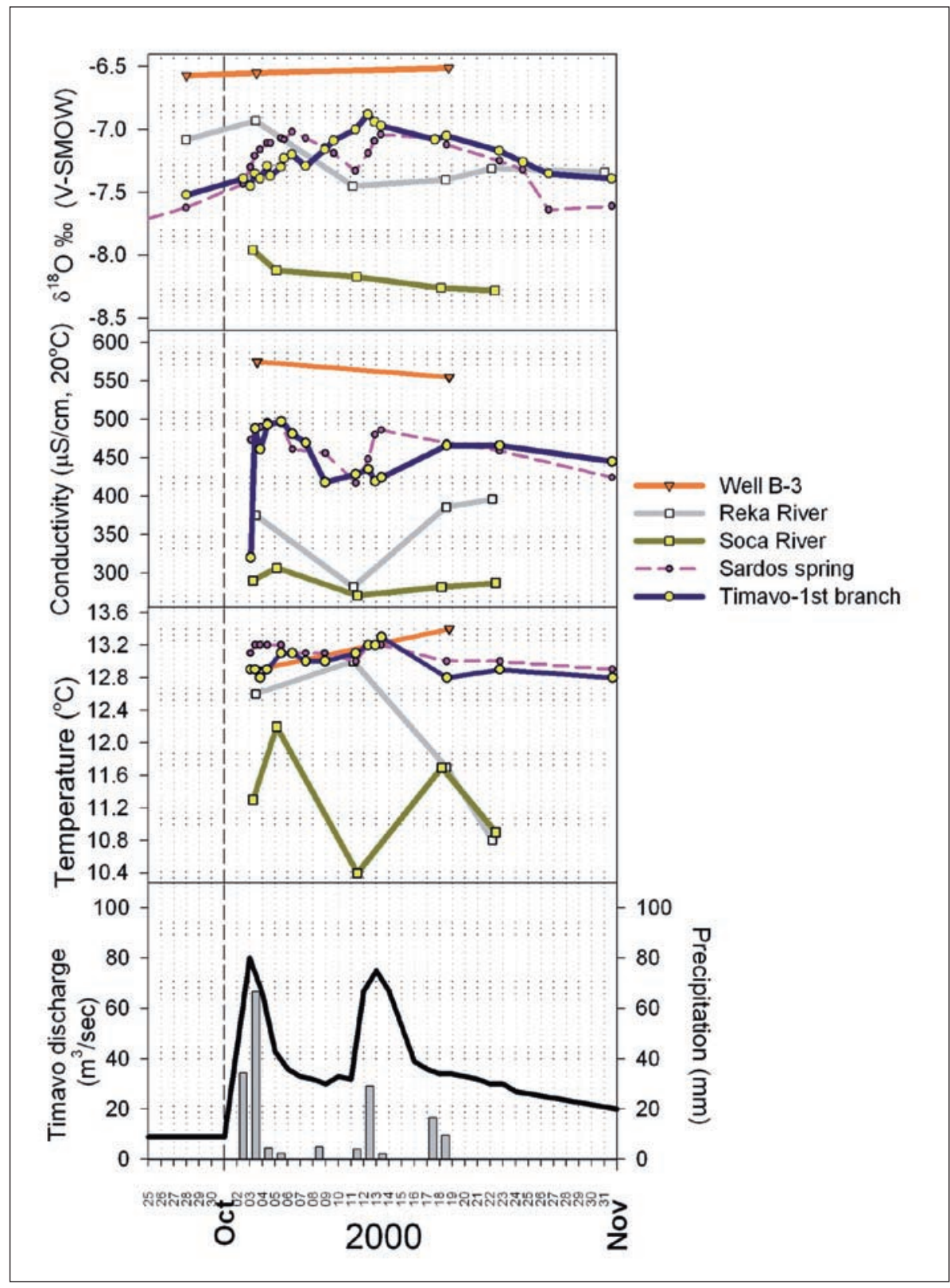

Fig. 9: $\delta^{18} \mathrm{O}$, temperature, and conductivity of the Timavo springs (1 $1^{\text {st }}$ branch), Reka River, Sardos spring, Soča River and well B-3 during storm events, 2000. Total discharge of the Timavo springs is provided for reference.

Judging from the published map of the exploration, it is evident that the main conduits that feed the Timavo have a width greater than $10 \mathrm{~m}$ in some sections.

Travel times on the order of 1-2 months are not unreasonable. The straight-line distance from the sinking reach of the Soča to the springs is approximately $12 \mathrm{~km}$. An estimated transit time of 2 months is thus equivalent to a mean flow velocity of $0.0023 \mathrm{~m} / \mathrm{sec}$, or approximately $200 \mathrm{~m} /$ day. This is a typical value for karstic conduits
(Ford \& Williams, 1989). In the zone where the Soča and Vipava Rivers begin to lose water underground, the thickness of the alluvial fill directly beneath the confluence of the two rivers varies between $50 \mathrm{~m}$ and $70 \mathrm{~m}$ (Morgante et al., 1966). Thus, this is a minimum distance that the sinking surface water must flow before it encounters the karstified limestone bedrock. Taking the minimum thickness of $50 \mathrm{~m}$ as the distance the water must traverse in 2 months before encountering fast flow in large karst conduits, the flow velocity through the alluvial aquifer is thus on the order of $0.83 \mathrm{~m} /$ day. Well logs from the alluvial aquifer of the Soča indicate that the sediments vary between coarse conglomerates and gravels to finer sand and clay mixtures (Morgante et al., 1966). Therefore, it is possible that the river water sinks relatively slowly through the alluvial sediments before moving quickly through conduits in the limestone bedrock to the springs. Assuming that once the water has entered the conduit system it is able to reach the outlet at a spring in matter of days, then the transit time is mostly a function of the movement of the water through the alluvial aquifer in the river plain. It is evident that the Soča River has a persistent, widespread influence on the ground-water resurgence of the Kras over a short time scale. Direct tracing of the Soča River from where it begins to sink downstream of Gorizia to these resurgence points could verify the transit time estimated by the time series analysis. This could be accomplished using artificial tracers injected directly into boreholes that bypass the alluvium and that intersect deep voids within the karstified bedrock (see Bidovec, 1967). 

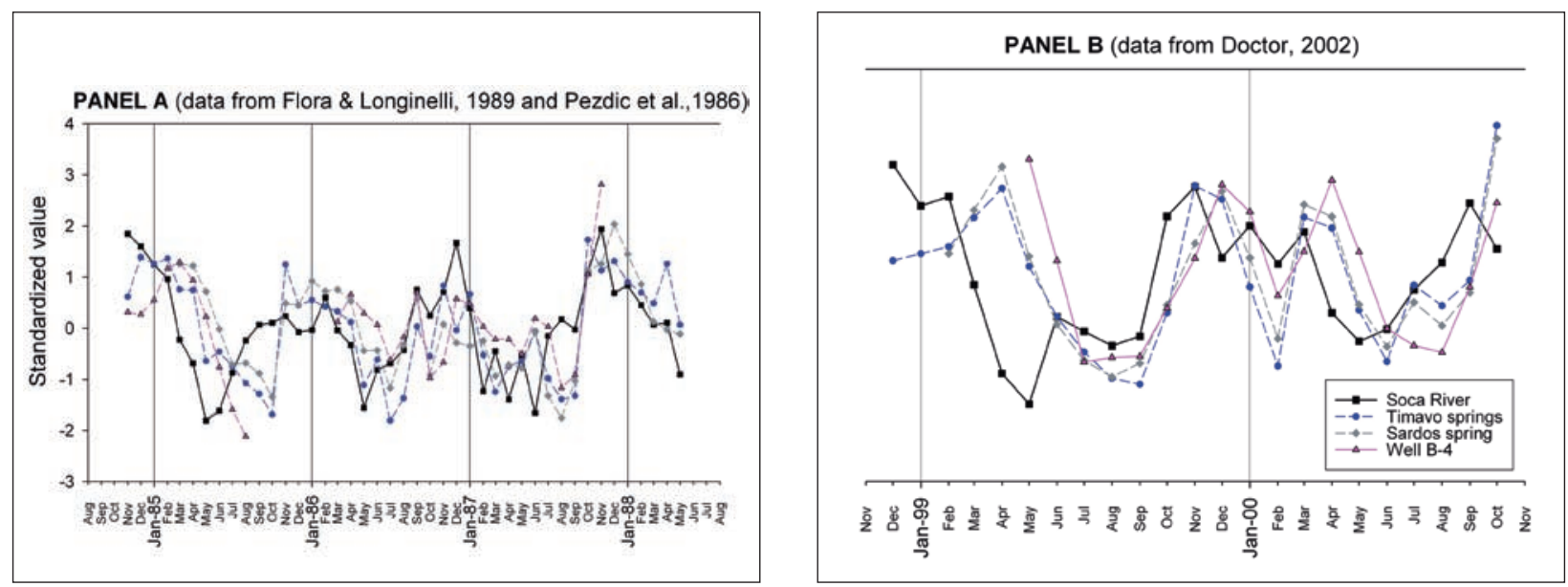

Fig. 10: Standardized, de-trended time series of mean monthly $\delta^{18} \mathrm{O}$ data from the Soča River, Timavo springs, Sardos spring, and Well B-4. Panel A shows data from 1984-1988. Panel B shows data from 1998-2000.

\section{CONCLUSION}

In the case study presented here, the natural tracers present in the water yielded the information that led to identification and quantification of the primary sources to the Kras aquifer resurgence. Although decades of water tracing with artificial tracers have proven the connection between the Timavo springs and the Reka River, those efforts drew attention away from the major source of water to the springs: the Soča River. It is estimated here that the Soča River supplies $75 \%$ of the flow to the smaller springs and water supply wells of the resurgence zone and $56 \%$ of the flow at the Timavo springs under average flow conditions. The Reka River apparently dominates the flow at the Timavo Springs for only brief periods (several days) during flood events. In effect, the Reka River "punctuates" the longer-term trend in water quality of the Timavo springs, and has little or no effect on the other ground waters of the aquifer resurgence zone. Although the Reka River vanishes totally at the Škocjan Caves, its flow comprises a fraction (less than 15\%) of the Timavo spring flow under average flow conditions. Some of the Reka flow emerges at springs further southeast along the Adriatic coast, as proven by previous tracing tests. It is possible that a significant proportion of the Reka flow is lost to submarine spring discharge under average and low flow conditions. This hypothesis awaits testing through further study.

The Kras aquifer contains a water component that appears to be impacted by anthropogenic activities as evidenced by high $\mathrm{Cl}^{-}$and $\mathrm{SO}_{4}^{2-}$ concentrations from a non-seawater source. The Brestovica water supply (well B-4) is most affected by this component, especially dur- ing high flow conditions when $\mathrm{Cl}^{-}$concentrations reach over $50 \mathrm{ppm}$ and the estimated anthropogenic proportion is on the order of $30 \%$. The source is apparently linked to the local shallow circulation in and around the northwest resurgence zone; however, the exact source is unknown. Further measurements of the springs, wells, and caves in the vicinity of Monfalcone is encouraged to better characterize and delineate the extent of this high$\mathrm{Cl}^{-}$component, and to develop well-head protection strategies for the supply well. Experimental dye tracing from local caves intersecting the water table to the well may shed light on the pathways of overflow to this well during recharge events.

For regional aquifers, tracing with dyes or other artificial tracers may not be sufficient to construct a water balance or characterize the storage capacity of the aquifer. The advantages of tracing with dyes or other artificial tracers are that a successful trace 1) identifies connections between the points of tracer input and the points of tracer recovery, 2) provides information on the velocity of flow between those points, and 3) provides information on the dilution or loss of tracer during transit. However, dye tracing describes only the fast-flow conduit portions of a karst aquifer, which are in fact the zones of least storage potential. Therefore, dye tracing alone is not an effective means of carrying out a regional-scale water resource investigation that requires a quantitative estimation of the proportion of outflow derived from more diffuse aquifer storage within karst systems characterized by a large phreatic component such as that of the Kras region. Dye traces should be combined with detailed 
chemical and isotopic analyses of frequently collected water samples whenever possible to observe the natural variation in environmental chemistry. In conclusion, it is hoped that the results from this investigation may pro- vide a useful case study to aid in answering questions for future sustainable management of the water resources of other karst aquifers.

\section{ACKNOWLEDGMENTS}

Several people were instrumental in providing the support and guidance for this research, particularly E. Calvin Alexander, Jr. of the University of Minnesota, Minneapolis; Milena Horvat and Sonja Lojen of the Jožef Stefan Institute, Ljubljana; Janko Urbanc from the Geological Survey of Slovenia, Ljubljana; Antonio Longinelli of the University of Parma; and Willibald Stichler of the Institute for Hydrology, Neuherberg. I must also acknowledge the aid of several key persons and agencies without whom I would not have accomplished this research. They are:, Fabio Gemiti from A.C.E.G.A. Trieste, Franco Cucchi, Onelio Flora, and Laura Genoni from the University of Trieste, Metka Petrič and Janja Kogovšek from the Karst Research Institute, Postojna, the Kraški Vodovod, Sežana, Francesca Serra and Reno Semararo from Geokarst Engineering s.r.l., Trieste, and Agnes Šomen from the Health Institute of Koper. Funding was provided by the U.S. Fulbright and David L. Boren fellowship programs, and the University of Minnesota, Dept. of Geology \& Geophysics.

\section{REFERENCES}

A.C.E.G.A. Trieste (1988) Il problema dellacqua nella provincia di Trieste. Trieste: Arti Grafiche Smolars S.p.A, 28 pp.

Bidovec, F., 1967: The hydrosystem of karstic springs in the Timavo basin. In: Hydrology of Fractured Rocks, vol 1. AIHS: London, 263-274.

Boegan, E., 1938. Il Timavo - Studio sull'idrografia carsica subaerea e sotterranea. Mem. Ist. Ital. Di Spel., serie Geol. E Geogr., Mem. II., Trieste.

Cancian, G., 1987: Lidrologia del Carso goriziano-triestino tra l'Isonzo e le risorgive del Timavo. Studi Trentini di Scienze Naturali, 64, 77-98.

Cancian, G., 1988: Significato idrologico della concentrazione di ossigeno e anidride carbonica nelle acque sotteranee tra il lago Doberdò e le risorgive del Timavo. Mondo Sottorraneo, Udine, 12(1/2), 11-29.

Civita, M., Cucchi, F., Eusebio, A., Garavoglia, S., Maranzana, F. \& Vigna, B., 1995: The Timavo hydrogeologic system: an important reservoir of supplementary water resources to be reclaimed and protected. Acta Carsologica, 24, 169-186.

Cucchi, F., Pirini Radrizzani, C., \& Pugliese, N., 1987: The carbonate stratigraphic sequence of the Karst of Trieste (Italy). Mem. Soc. Geol. It. (Proc. Int. Symp. Evolution of Karstic Carbonate Platform: Relation with other Peridadriatic Carbonate Platforms), 40, 35-44.
Cucchi, F., Giorgetti, F., Marinetti, E., Kranjc, A., 1997: Experiences in monitoring Timavo River (Classical Karst). In: Tracer Hydrology 97 (A. Kranjc, ed.) A.A. Balkema: Rotterdam, 167-172.

Cucchi, F. Forti, P., Marinetti, E., and Zini, L., 2000: Recent developments in knowledge of the hydrogeology of the "Classical Karst". Acta Carsologica, 29, 55-78.

Cucchi, F., Marinetti, E., Potleca, M., and Zini, L., 2001. Influence of geostructural conditions on the speleogenesis of the Trieste karst (Italy). Geologica Belgica, 4(3-4), 241-250.

Cucchi, F., and Zini, L., 2002: Underground Timavo river monitoring (Classical Karst). Acta Carsologica, 31(1), 75-84.

D’Amelio, L., Flora, O., Longinelli, A. (1994) Environmental isotope data: oxygen isotope concentration in precipitation in N-E Italy (Friuli-Venezia Giulia). Miner. Petrogr. Acta, vol. 37, pp. 113-124.

Dansgaard, W., 1964: Stable isotopes in precipitation. Tellus, 16: 436-468.

Deines, P., Langmuir, D., and Harmon, R. (1974) Stable carbon isotope ratios and the existence of a gas phase in the evolution of carbonate ground waters. Geochimica et Cosmochimica Acta, vol. 38, p.11471164. 
Doctor, D.H., 2002: The Hydrogeology of the Classical Karst (Kras) Aquifer of Southwestern Slovenia. Ph.D. dissertation, University of Minnesota, Minneapolis, 212 p.

Doctor, D.H., Lojen, S. and Horvat, M., 2000: A stable isotope investigation of the Classical Karst aquifer: Evaluating karst ground-water components for water quality preservation. Acta Carsologica, 29 (1), 79-92.

Doctor, D.H., Alexander, E.C., Jr., Petrič, M., Kogovšek, J., Urbanc, J., Lojen, S., and Stichler, W., 2006: Quantification of karst aquifer discharge components through end-member mixing analysis using natural chemistry and stable isotopes as tracers. Hydrogeology Journal, 14, 1171-1191.

Doctor, D.H. and Alexander, E. C., Jr., 2005: Interpretation of water chemistry and stable isotope data from a karst aquifer according to flow regimes identified through hydrograph recession analysis. U.S. Geological Survey Karst Interest Group Proceedings, Rapid City, South Dakota, September 12-15, 2005 (E. L. Kuniansky, ed.). USGS Scientific Investigations Report 2005-5160, p. 82-92.

El-Hakim, M., and Bakalowicz, M., 2007: Significance and origin of very large regulating power of some karst aquifers in the Middle East: Implication on karst aquifer classification. Journal of Hydrology, 333, 329-339.

Eriksson, E., Mosetti, F., Hodoscek, K., Ostanek, L., 1963: Some new results on the karstic hydrology with the employ of tritiated water as tracer. Boll. Geof. Teor. Appl., 5(17), 18-32.

Eriksson, E., 1983: Stable isotopes and tritium in precipitation. In: Guidebook on Nuclear Techniques in Hydrology. IAEA Technical Reports Series no. 91, Vienna: International Atomic energy Agency. pp. 19-27.

Flora, O. and Longinelli, A., 1989: Stable isotope hydrology of a classical karst area, Trieste, Italy. In: Isotope Techniques in the Study of Fractured and Fissured Rocks, International Atomic Energy Agency (IAEA): Vienna, 306 pp.

Ford, D.C. and Williams, P.W., 1989: Karst Geomorphology and Hydrology. New York: Chapman \& Hall, $601 \mathrm{pp}$.

Gabrovšek, F. and Peric, B, 2006: Monitoring the flood pulses in the epiphreatic zone of karst aquifers: the case of Reka river system, karst plateau, SW Slovenia, Acta Carsologica, 35(1), 35-45.

Galli, M., 1999: Timavo: Esplorazione e studi. Supplemento no. 23 di Atti e Memorie della Commissione Grotte “Eugenio Boegan”, Trieste, 195 p.
Gams, I., 1993: Origin of the term "karst", and the transformation of the Classical Karst (Kras). Environmental Geology, 21, 110-114.

Gemiti, F., and Licciardello, M., 1977: Indagini sui rapporti di alimentazione delle acque del Carso triestino e goriziano mediante l'utilizzo di alcuni traccianti naturali. Annali Gruppo Grotte Ass. XXX Ott., sez. C.A.I. Trieste, 6, 43-61.

Gemiti, F., 1984a: La portata del Timavo alle risorgive di S. Giovanni di Duino. Annali Gruppo Grotte Ass. $30^{\circ}$ Ott., Trieste, 7, 23-41.

Gemiti, F., 1984b: Nuova ed originale prova di marcatura delle acque del Timavo. Annali Gruppo Grotte Ass. 30ºtt., sez. C.A.I. Trieste, 7, 43-62.

Gemiti, F., 1994: Indagini idrochemiche alle risorgive del Timavo. Atti e Memorie della Commissione Grotte "E. Boegan", 30, 73-83.

Gemiti, F., 1996: Portata liquida e portata solida del Timavo alle risorgive di S. Giovanni di Duino. Hydrores-Annuario 1995, Trieste, 13, 74-88.

Gemiti, F., 1998: Marcatura delle acque del Timavo a seguito di un versamento di idrocarburi nella valle della Recca e interpretazione del'evento mediante l'utizzo di dati meteorologici, idrologici, idrochimici. Annali Gruppo Grotte Ass. XXX Ott, 10, 930104.

Guglia, P., 1994: Risultati esplorativi del Progetto Timavo (1990-1993). Atti e Memorie della Commissione Grotta “E. Boegan”, 31/1992-93, 25-48.

Habič, P., 1989: Kraška bifurkacija Pivke na jadransko Črnomorskem razvodju (Pivka karst bifurcation on Adriatic-Black Sea watershed), Acta Carsologica, 18, 233-164.

Kranjc, A. (ed.), 1997: Slovene Classical Karst-"Kras". Postojna: Institut za raziskovanja krasa ZRC SAZU, 254 pp.

Krivic, P., 1981: Etude hydrodynamique d'un aquifère karstique côtiere: le Kras de Slovenie, Yougoslavie. Accadèmie Montpellier, Univ. Sc. Techn. Languedoc, Thèse de Docteur-Ingénieur Université Montpellier II: $108 \mathrm{pp}$.

Krivic, P., 1982a: Variations naturelles de niveau piézométrique d'un aquifère kartsique. Geologija, 25(1), 129-150.

Krivic, P., 1982b: Transmission des ondes de marée à travers l'aquifére côtier de Kras. Geologija, 25(2), 309-325.

Krivic, P., 1983: Interprétation des essais par pompage réalisés dans un aquifére karstique. Geologija, 26, 149-186. 
Krokos, A., 1998: Ulteriori studi geochimico-isotopici su alcune sorgenti carsiche costiere dellarea triestina: considerazioni idrologico-ambientali. Bachelor's Thesis in Geological Sciences, University of Trieste, Italy.

Maillet, E., 1905. Essais d'Hydraulique Souterraine et Fluviale. Herman, Paris, France, 218 pp.

Morgante, S., Mosetti, F., Tongiorgi, E.,1966: Moderne indagini idrologiche nella zona di Gorizia. Bollettino di Geofisica Teorica ed Applicata, 8(30), 114-137.

Mosetti, F., 1965: Nuova interpretazione di un esperimento di marcatura radioattiva del Timavo. Bollettino di Geofisica Teorica ed Applicata, 2(8).

Mosetti, F., 1966: Lo stato delle attuali conoscenze sull'idrologia carsica e relative ripercussioni sul problema dell'alimentazione idrica di Trieste. Atti del Museo Civico di Storia Naturale, Trieste, 25(4): 73-105.

Mosetti, F. \& D’Ambrosi, C., 1963: Alcune ricerche preliminari in merito a supposti legami di alimentazione fra il Timavo e l'Isonzo. Bollettino di Geofisica Teorica ed Applicata., n. 17.
Polli, S., 1971: Quattro anni di meteorologia etc. Atti e memorie della Commissione Grotta E. Boegan, vol 10, Trieste.

Pezdič, J., Dolenec, T., Krivic, P., Urbanc, J., 1986: Environmental isotope studies related to ground-water flow in the central Slovenian karst region, Yugoslavia. $5^{\text {th }}$ International Symposium on Underground Water Tracing (SUWT), Athens, 91-100.

Ravbar, N., 2004: Drinking water supply from karst water resources (The example of the Kras plateau, SW Slovenia). Acta Carsologica, 33(1), 73-84.

Rojšek, D., 1996: Velika Voda-Reka, a karst river. Acta Carsologica, 25, 193-206.

Timeus, G., 1928: Nei misteri del mondo sotterraneo. Risultati delle ricerche idrogeologiche sul Timavo 1895-1914, 1918-1927. Alpi Giulie, vol. 29, 1. In: Atti e Mem. Comm. Grotte "E. Boegan”, 22, 117-133.

Urbanc, J., and Kristan, S., 1998: Isotope investigation of the Brestovica water source during an intensive pumping test. RMZ - Materials and Geoenvironment, 45(1-2), 187-191. 
